\title{
Regulation of hypothalamic prohormone convertases 1 and 2 and effects on processing of prothyrotropin- releasing hormone
}

\author{
Vanesa C. Sanchez, ${ }^{1}$ Jorge Goldstein, ${ }^{1}$ Ronald C. Stuart, ${ }^{1}$ Virginia Hovanesian, ${ }^{1}$ Lihong Huo, ${ }^{2}$ \\ Heike Munzberg, ${ }^{2}$ Theodore C. Friedman, ${ }^{3}$ Christian Bjorbaek, ${ }^{2}$ and Eduardo A. Nillni ${ }^{1}$
${ }^{1}$ Division of Endocrinology, Department of Medicine, Brown Medical School, Rhode Island Hospital, Providence, Rhode Island, USA.
2Division of Endocrinology, Beth Israel Deaconess Medical Center and Harvard Medical School, Boston, Massachusetts, USA. ${ }^{3}$ Endocrinology Division, Charles R. Drew University, Los Angeles, California, USA.

\begin{abstract}
Regulation of energy balance by leptin involves regulation of several neuropeptides, including thyrotropinreleasing hormone (TRH). Synthesized from a larger inactive precursor, its maturation requires proteolytic cleavage by prohormone convertases 1 and 2 (PC1 and PC2). Since this maturation in response to leptin requires prohormone processing, we hypothesized that leptin might regulate hypothalamic PC1 and PC2 expression, ultimately leading to coordinated processing of prohormones into mature peptides. Using hypothalamic neurons, we found that leptin stimulated PC1 and PC2 mRNA and protein expression and also increased PC1 and PC2 promoter activities in transfected 293T cells. Starvation of rats, leading to low serum leptin levels, decreased PC1 and PC2 gene and protein expression in the paraventricular nucleus (PVN) of the hypothalamus. Exogenous administration of leptin to fasted animals restored PC1 levels in the median eminence (ME) and the PVN to approximately the level found in fed control animals. Consistent with this regulation of PCs in the PVN, concentrations of TRH in the PVN and ME were substantially reduced in the fasted animals relative to the fed animals, and leptin reversed this decrease. Further analysis showed that proteolytic cleavage of pro-thyrotropin-releasing hormone (proTRH) at known PC cleavage sites was reduced by fasting and increased in animals given leptin. Combined, these findings suggest that leptin-dependent stimulation of hypothalamic TRH expression involves both activation of $t r b$ transcription and stimulation of PC1 and PC2 expression, which lead to enhanced processing of proTRH into mature TRH.
\end{abstract}

\section{Introduction}

Peptide hormones and neuropeptides are often synthesized as larger inactive precursor proteins that are subjected to sequence-specific cleavages in a tissue- and compartment-specific manner by processing enzymes $(1,2)$. These include the prohormone convertases (PCs), which are members of the mammalian family of subtilisinlike endoproteases thought to be responsible for the cleavage that generates shorter forms of many prohormones and proneuropeptides at the carboxyl terminus of paired basic residues. These peptide intermediates are subsequently cleaved by exopeptidases, such as carboxypeptidase E (CPE) or carboxypeptidase D, to remove the $\mathrm{C}$-terminal basic amino acids $(3,4)$. In addition, some peptides are further modified by acetylation at their amino terminus by $\mathrm{N}$-acetyl-transferases, or by amidation at their carboxyl terminus by the action of peptidylglycine $\alpha$-amidating monooxy-

Nonstandard abbreviations used: carboxypeptidase E (CPE); hypothalamicpituitary-thyroid (HPT); immunohistochemistry (IHC); median eminence (ME); $\alpha$-melanocyte-stimulating hormone (MSH); neuropeptide Y (NPY); paraventricular lateral magnocellular cell (PaLM); paraventricular medial parvocellular cell (PaMP); paraventricular nucleus $(\mathrm{PVN})$; phosphorylation of signal transducer and activator of transcription 3 (P-STAT3); preproTRH ${ }_{83-106}(\mathrm{pEH} 24)$; prohormone convertase (PC); pro-neuropeptide Y (proNPY); proopiomelanocortin (POMC); pro-thyrotropin-releasing hormone (proTRH); thyroid-stimulating hormone (TSH); thyrotropinreleasing hormone (TRH); thyroxine $\left(\mathrm{T}_{4}\right) ; 3,5,3^{\prime}$-triiodothyronine $\left(\mathrm{T}_{3}\right)$.

Conflict of interest: The authors have declared that no conflict of interest exists.

Citation for this article: J. Clin. Invest. 114:357-369 (2004)

doi:10.1172/JCI200421620. genase enzyme (PAM) (5). These modifications are believed to be essential for peptide stability or to ensure specific recognition with their corresponding receptor. Posttranslational processing of precursors like pro-thyrotropin-releasing hormone (proTRH) (6, $7)$ and proopiomelanocortin (POMC) (8) is essential for maturation of their respective bioactive moieties (9). The neuropeptides derived from these precursors, including thyrotropin-releasing hormone (TRH) and $\alpha$-melanocyte-stimulating hormone (MSH), are upregulated by leptin $(10,11)$ and are known to be critical in the regulation of energy balance $(11,12)$. Leptin is produced in adipose tissue and provides information on energy stores and energy balance to brain centers involved in regulating appetite, energy expenditure, and neuroendocrine function (11,13-18). We hypothesized that availability of the mature peptides in the hypothalamus in response to leptin requires an increase in both gene expression and posttranslational processing by the action of the PCs.

Two members of the PC family, PC1 and PC2, are specifically found in the secretory granules of neural and endocrine cells (19-21). Their involvement in the processing of neuropeptide precursors has been suggested by the finding that PC1 and PC2 transcripts and protein products are widely distributed in different areas of the brain, including cerebral cortex, hippocampus, and hypothalamus $(22,23)$. In the hypothalamus, these enzymes displayed an extensive overlapping pattern of expression. Both convertases are effectively targeted to the regulated secretory pathway, where they process many neuropeptide precursors 
in the brain and prohormones in the pituitary, including proTRH $(7,24)$, POMC (9), prosomatostatin (25), provasopressin (26), pro-neuropeptide Y (proNPY) (27), proneurotensin (28), proenkephalin (29), and pro-cocaine amphetamine-regulated transcript (proCART) (30). The critical role of PC1 and PC2 in prohormone processing is underscored by studies of animals that lack the genes encoding PC1 (31) and PC2 (32), as well as 7B2 (33, $34)$, a neuropeptide essential for the maturation of PC2. In addition, a patient with a compound heterozygous mutation in the PC1 gene that results in nonfunctional PC1 had severe childhood obesity (35). Similar obese conditions were found in a patient with a defect in POMC processing (36). As PC1 and PC2 are essential for the processing of a variety of proneuropeptides, alterations in the expression and protein biosynthesis of PC1 and PC2 are likely to have profound effects on neuropeptide homeostasis. The role of CPE has been elucidated in Cpe fat $/ C p e^{f a t}$ mice, which lack functional CPE because of a naturally occurring mutation (37). We found that hypothalamic TRH in these mice was depressed by at least $75 \%$ compared with that in wild-type controls (38). These mice cannot maintain their body temperatures when exposed to cold due to substantial decrease of hypothalamic TRH and reduction in thyroid hormone.

Thyroid hormone, the peripheral end product of the hypothalamic-pituitary-thyroidx axis, is a key stimulator of energy expenditure; it achieves this stimulation largely by increasing the basal metabolic rate $(6,11)$ in many cells through the action of $3,5,3^{\prime}$-triiodothyronine $\left(T_{3}\right)$ on uncoupling protein-3 (39). The regulation of this axis takes place through the release of hypophysiotropic TRH from neurons in the medial and periventricular parvocellular subdivisions of the paraventricular nucleus (PVN) of the hypothalamus to stimulate thyroid-stimulating hormone (TSH) secretion from the pituitary, which in turn stimulates the synthesis and release of thyroid hormone. Alterations in plasma levels of thyroid hormone regulate the biosynthesis and secretion of TRH from these neurons as well as at the level of the pituitary to modulate the HPT axis (40). During fasting, however, this regulatory system is altered, such that decreased circulating thyroid hormone levels are associated with a reduction in the biosynthesis of TRH and the secretion of TSH $(41,42)$. By creating a state of transient, central hypothyroidism, the resulting reduction of thyroid hormone-mediated metabolism may serve as an important energy conservation mechanism until refeeding occurs. This is believed to be similar to the condition of "sick euthyroid" seen in critically ill patients (43). It has also been shown that centrally acting TRH, independent of endocrine action, regulates several metabolic and behavioral parameters in rats and Siberian hamsters, including food intake and locomotor activity $(44,45)$.

In this study we present evidence that leptin stimulates the biosynthesis of PC1 and PC2, leading to an increase in the conversion of proTRH into mature TRH and other proTRH-derived peptides. These findings bring new insight to our understanding of how the maturation of neuropeptides and hormones is linked to the activity of their processing enzymes.

\section{Results}

Leptin stimulates PC1 and PC2 $\mathrm{mRNA}$ and protein levels in primary bypothalamic neuronal cultures. Since PC1 and PC2 are key enzymes involved in the posttranslational processing of hypothalamic prohormones such as proTRH and $\operatorname{POMC}(7,9)$, both of whose expression is upregulated by leptin $(17,46)$, we hypothesized that leptin might also stimulate expression of PC1 and PC2, leading to more efficient maturation of the biologically active neuropeptides. To test this possibility, we first measured the mRNA expression of PC1 and PC2 by Northern blot analysis in primary hypothalamic cultures after leptin stimulation. We have previously demonstrated high levels of base-line PC1 and PC2 expression in these cells (47). The results depicted in Figure 1A show that leptin treatment $(10 \mathrm{nM})$ for 6 hours led to an approximately fourfold and three-

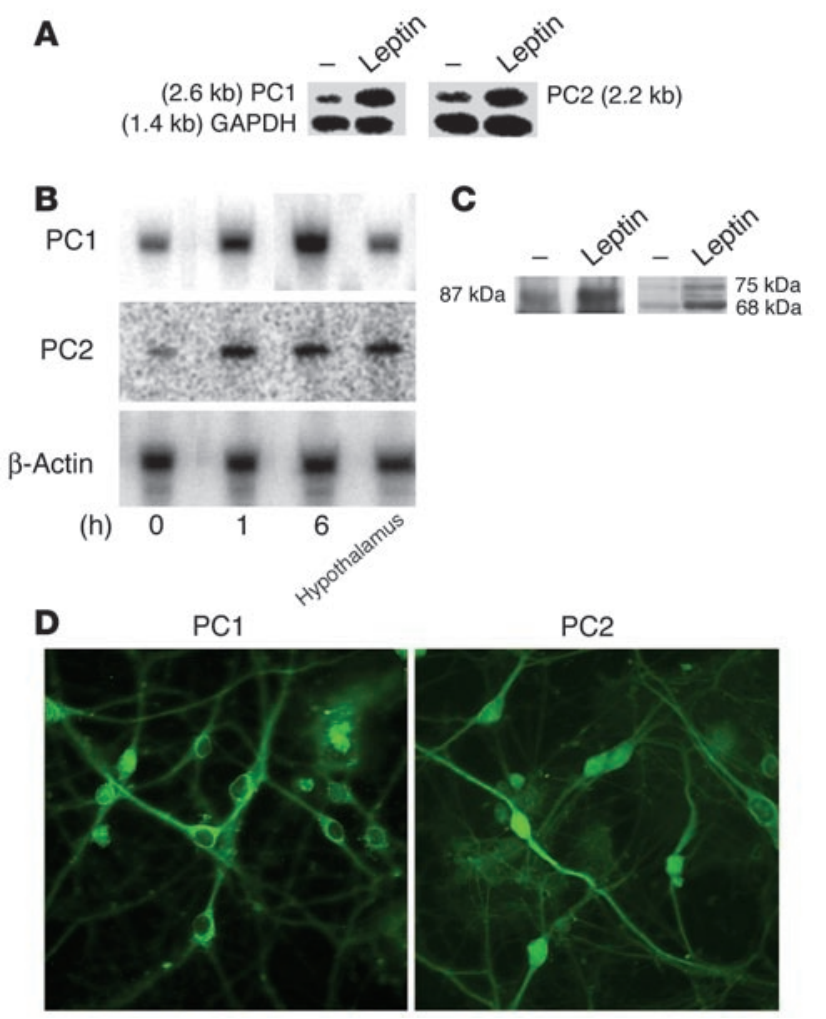

Figure 1

Leptin stimulates PC1 and PC2 mRNA and protein levels in primary hypothalamic neuronal cultures. (A) Northern blot analysis of leptintreated primary neurons. Primary neuronal hypothalamic cultures were serum-deprived overnight and then treated with leptin for 6 hours. Total RNA was then isolated and subjected to Northern blotting. The upper bands are PC1 mRNA (left) and PC2 mRNA (right). The lower bands are GAPDH mRNA. Cells were left untreated or treated with $5 \mathrm{nM}$ or 10 nM leptin for 6 hours. PC1, PC2, and GAPDH mRNA had the expected sizes of 2.6, 2.2, and $1.4 \mathrm{~kb}$, respectively. (B) Time-dependent ${ }^{32} \mathrm{P}-\mathrm{RT}$ PCR analysis in leptin-treated primary hypothalamic neurons. Primary neuronal hypothalamic cultures were serum-deprived overnight and then treated with $10 \mathrm{nM}$ leptin for various periods of time. Total RNA was then subjected to quantitative ${ }^{32} \mathrm{P}-\mathrm{RT}$-PCR using a limiting number of PCR cycles as described in Methods. The same amount of total RNA from adult rat hypothalamic tissue was analyzed in parallel. The upper panel represents PC1 mRNA and the middle panel PC2 mRNA. Bands in the lower panel represent levels of $\beta$-actin mRNA in the same samples, which did not change with time or treatment. (C) Western blot analysis for PC1 and PC2 in samples extracted from hypothalamic neurons treated with leptin. Hypothalamic neurons were treated with $10 \mathrm{nM}$ leptin for 6 hours. Protein lysates were then subjected to Western blotting for PC1 and PC2 proteins. PC1 and PC2 migrated with expected molecular masses of $87 \mathrm{kDa}$ and the processed form of 75 and $68 \mathrm{kDa}$, respectively. (D) Typical immunostaining distribution for PC1 and PC2 in primary cultures of hypothalamic neurons. 
A

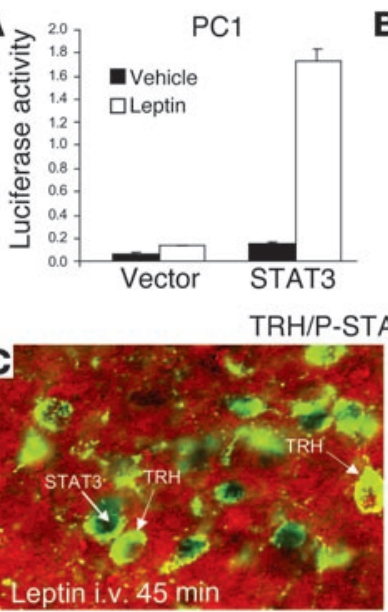

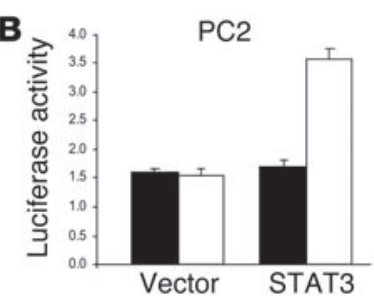

Vector

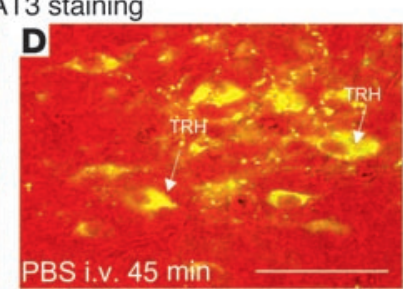

Figure 2

Leptin stimulates PC1 and PC2 promoter activity via STAT3 in transfected cells and activates STAT3 in TRH neurons in vivo. 293T cells were transfected with ObRb cDNAs together with PC1 $(\mathbf{A})$ or PC2 (B) promoter-luciferase reporter plasmids, and STAT3 expression vector or the corresponding empty vector was also cotransfected as indicated. A CMV-lacZ control plasmid was included in all transfections to correct for differences in transfection efficiencies. Serumdeprived cells were left unstimulated or treated with $20 \mathrm{nM}$ leptin for 6 hours, and luciferase activities were measured in the cell lysates. Luciferase activities were normalized with $\beta$-galactosidase activities measured in the same samples. This experiment was performed 3 times, each one in triplicate. Shown are means \pm SE. $\beta$-Galactosidase activities did not change with treatments. (C and D) Leptin-dependent STAT3 phosphorylation in TRH neurons in the PVN of rats. Animals were given a single i.v. injection of recombinant leptin $(1.0 \mathrm{mg} / \mathrm{kg})$ or vehicle (PBS) and killed 45 minutes later. Coronal brain sections were obtained and subjected to double IHC using anti-P-STAT3 nuclear (brown staining) and anti-proTRH cytoplasmic (green fluorescence) antiserum. Scale bar: $10 \mu \mathrm{m}$.

fold increase in mRNA expression of $\mathrm{PC} 1$ and $\mathrm{PC} 2$, respectively. This increase by leptin was also seen at 1 hour using quantitative ${ }^{32}$ P-RT-PCR (Figure 1B). The amount of PC1 and PC2 mRNA measured in these cultures was similar to the mRNA levels found in adult rat hypothalamus using the same amount of total mRNA. These convertases are produced as zymogens that undergo activation by removal of the $\mathrm{N}$-terminal prodomain and, in the case of $\mathrm{PC} 1$, by further truncation at the C-terminus. The major form of PC1 identified with this carboxyl-terminus antibody has a molecular mass of about $87 \mathrm{kDa}$, which is similar in size to the previously characterized form (48). It is most likely that smaller forms of PC1 are also present in these tissues but not recognized by this antibody, since further processing of PC1 removes the C-terminal side (49). Western blotting demonstrated that leptin treatment also resulted in an approximately twofold increase in PC1 protein levels, and an approximately threefold increase in proPC2 and PC2 (Figure 1C). Figure 1D depicts a typical immunostaining for PC1 and PC2 in the primary hypothalamic cultures $(6,7)$.

Leptin stimulates PC1 and PC2 promoter activity via STAT3 in transfected cells and activates STAT3 in TRH neurons in vivo. Having determined leptin-dependent stimulation of endogenous PC1 and PC2 mRNA in neuronal cells, we wanted to investigate whether this effect was mediated by increased transcription and to examine the role of the leptin-inducible transcription factor STAT3 $(50,51)$.

Since a neuronal cell line expressing endogenous leptin receptors and PC1 and PC2 has not been reported, we used a heterologous transfection system that we have described earlier $(10,52)$. Human embryonic kidney (293T) cells were transiently transfected with expression vectors of the long form of the leptin receptor (ObRb), together with PC1 (-971 bp) or PC2 (-781 bp) promoter-luciferase reporter plasmids. The cells were serum-deprived for $12-15$ hours after transfection, and then treated with $20 \mathrm{nM}$ leptin or vehicle for 6 hours; then luciferase activity was measured in cellular lysates. Leptin treatment resulted in a modest $(-70 \%)$ stimulation of the PC1 promoter activity (Figure 2A, empty vector) and no activation of the $\mathrm{PC} 2$ promoter (Figure $2 \mathrm{~B}$, empty vector) in cells only expressing ObRb. In contrast, when STAT3 was coexpressed in the cells, leptin robustly activated the PC1 promoter approximately sevenfold (Figure 2A, STAT3) and the PC2 promoter twofold (Figure 2B, STAT3). This shows that leptin can directly activate both the PC1 and the PC2 promoters in cells that express ObRb and that the STAT3 transcription factor can mediate this activation $(50,53)$. The fact that little activation of the 2 promoters is observed in cells without coexpression of STAT3 suggests that endogenous STAT3 protein levels are low in these cells. To further support a putative role of STAT3 in regulation of the PC1 and PC2 genes by leptin, we used double immunohistochemistry (IHC) to detect STAT3 phosphorylation in TRH neurons in vivo. As depicted in Figure 2, C and D, i.v. administration of leptin into rats results in rapid accumulation of phosphorylation of signal transducer and activator of transcription 3 (P-STAT3) in the nucleus of TRH neurons in the PVN, similar to what we have shown earlier (54).

Analysis of fasting and leptin-induced regulation of PC1 and PC2 $\mathrm{mRNA}$ and proteins in the PVN and median eminence of rats. Since fasting leads to lower levels of circulating leptin, we wanted to determine the effect of fasting on the levels of PC1 and PC2 in rats. Specifically, we focused on the PVN, a region containing proTRH-producing neurons, and the median eminence (ME), a region where TRH neuronal fibers secrete their processing products through their axon terminals in close contact with the originating portal vessels.

For this purpose, we first extracted mRNA from the PVN in animals subjected to 65 hours of fasting, in animals given recombinant leptin during the fasting period, and in fed controls. Fasted animals had an approximately $33 \%$ decrease in body weight after 65 hours of starvation as compared with fed controls (fed, $210 \pm 3.12$ $\mathrm{g}$, vs. fasted, $140.8 \pm 3.24 \mathrm{~g}, P<0.01)$. Fasted animals receiving leptin showed a further reduction in body weight $(\sim 50 \%, 116 \pm 1.6 \mathrm{~g}$, $P<0.01)$, consistent with earlier reports of a leptin-dependent increase in basic metabolic rate (55). As demonstrated by quantitative ${ }^{32} \mathrm{P}-\mathrm{RT}-\mathrm{PCR}$ and consistent with the results shown in Figure $1, \mathrm{~A}$ and $\mathrm{B}$, we found that in the PVN there was an approximately twofold decrease in the expression of PC1, PC2, and preproTRH mRNA after 65 hours of fasting (Figure 3). In contrast, PC levels were unaffected in the cerebral cortex (CC), a region outside of the hypophysiotropic area (Figure 3).

Next, by examining the protein levels of PC1 and PC2, we evaluated whether the observed changes in gene expression caused by fasting could be reversed by leptin. Figure 4A depicts a representative Western blot for PC1 derived from the PVN region, demonstrating a significant, approximately fourfold decrease as compared with PC1 in fed controls. Fasted animals receiving recombinant leptin showed PC1 levels slightly higher than those in fed controls. Similar to the PVN, the ME also showed a decrease in PC1 during fasting (about twofold), and leptin restored PC1 levels to those of 
A

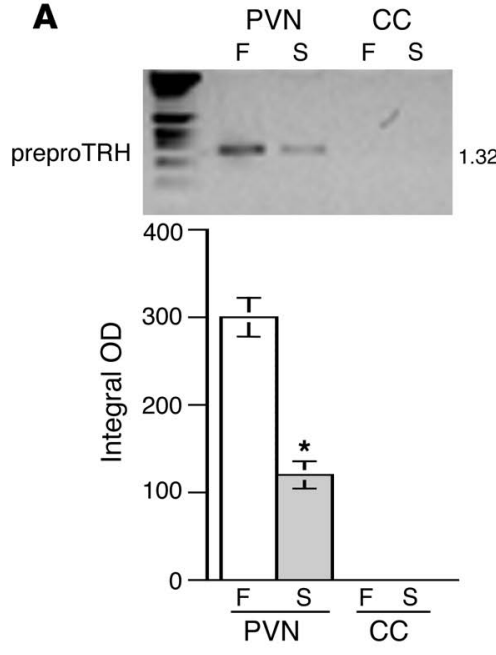

\section{C}

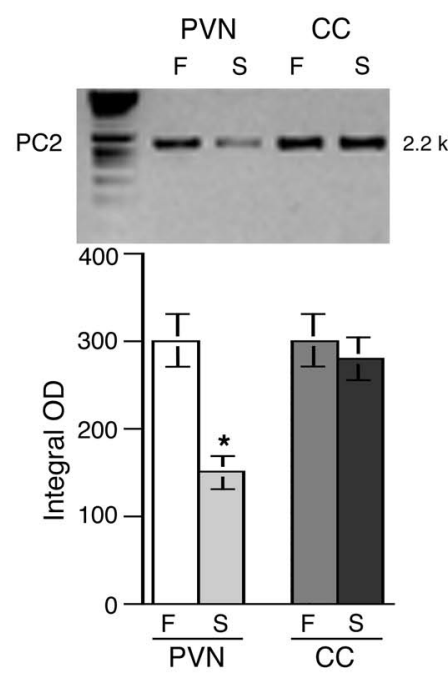

B
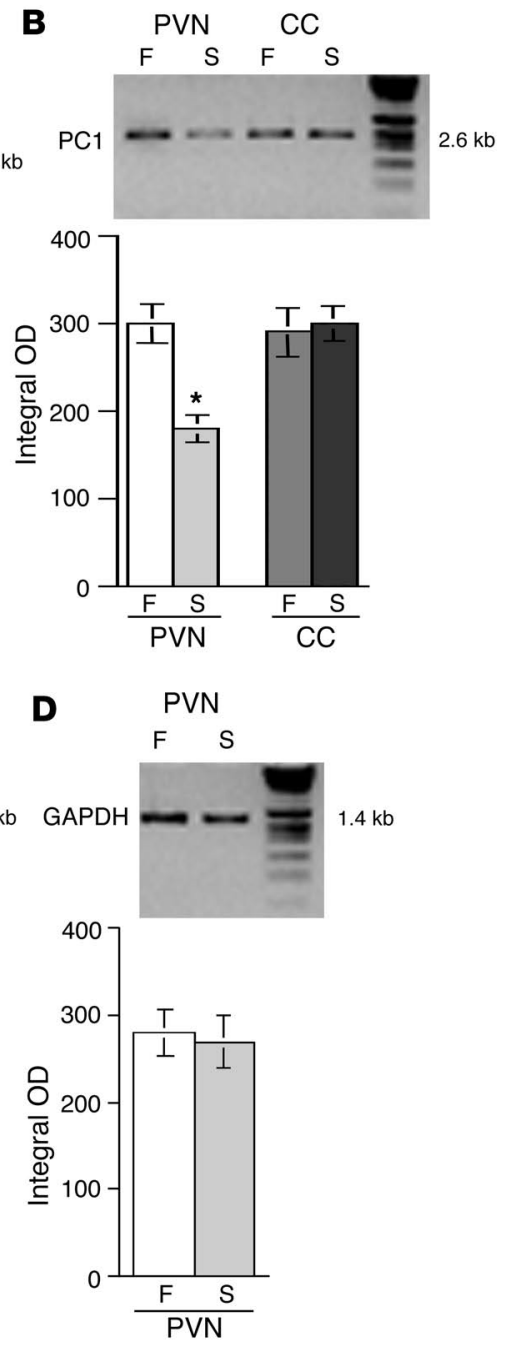

Figure 3

Analysis of fasting- and leptin-induced regulation of PC1 and PC2 mRNA in the PVN and ME of rats. (A-D) A typical quantitative ${ }^{32} \mathrm{P}-\mathrm{RT}-\mathrm{PCR}$ for TRH, PC1, and PC2 using a limiting number of PCR cycles (see Methods) in PVN and CC tissues derived from fed $(F)$ and starved (S) animals. Integrated optical density using NIH Image software for PC1, PC2, and TRH in the 2 brain areas was analyzed. ANOVA was followed by a multiple comparison using a Tukey-Kramer test. ${ }^{*} P<0.01$, significant difference at this level. GAPDH mRNA was analyzed as an endogenous control.

ed a significant decrease of PC1 immunoreactivity in fasted animals compared with fed controls (Figure 5, $A$ and $B$ ). This particular region of the hypothalamus is the location of the hypophysiotropic TRH neurons (see high-magnification images indicated by arrows). In the same brain section, the PaLM subdivision, which also expresses PC1, PC2 (22), and proTRH (58), did not exhibit changes in PC1 during fasting (Figure 5, A and $\mathrm{B}$; see high-magnification images). Similar to PC1, PC2 also showed a decrease in the PaMP region (Figure 6, A and $\mathrm{B}$ ) and to some extent in the PaLMs. PC1 staining in the ME of fed animals is depicted in Figure 5D. In fasted animals, the staining was strongly diminished (Figure 5D). Similar changes were observed in the anterior and posterior ME (not shown). For PC2, no differences were observed between fed and starved animals (Figure 6, C and D). Other brain areas, such as the CC, showed no changes in PC1 and PC2 (Figure 5, E and F, and Figure 6, E and F).

Fasting and leptin regulate biosynthesis of proTRH and alter its posttranslational processing in the PVN and ME of rats. We next wanted to determine whether the changes in expression of PC1 and PC2 observed during fasting and after leptin administration were also

fed controls. In contrast, no significant differences in PC2 protein amounts were observed in whole-tissue extracts from the PVN or ME (Figure 4B). The CC did not show any changes in the levels of PC1 and PC2 (Figure 4, A and B). We next determined whether proSAAS, an endogenous inhibitor of PC1 activity (56), and the 7B2 peptide (57), a facilitator of $\mathrm{PC} 2$ maturation, were regulated by leptin. Figure 4C shows that proSAAS peptide increases only in the ME of starved animals, consistent with a dramatic decrease in PC1 observed in the ME (Figures 4A and 5D). No differences in the level of pro7B2 $(27 \mathrm{kDa})$ and its smaller form of $21 \mathrm{kDa}$ were observed during fasting (Figure 4D). Interestingly, the ratio of 21to $27-\mathrm{kDa}$ forms was higher in the PVN than in the ME for all conditions. Hypothalamic neuronal protein contents of tubulin and microtubule-associated protein-2 (MAP-2) did not differ among the 3 groups (data not shown).

Immunohistochemical analysis of fasting-induced regulation of PC1 and PC2 in the PVN and ME of rats. Using IHC, we further analyzed the effects of fasting on PC1 and PC2 expression in the PVN and the ME. Hypothalamic sections from fed rats showed strong immunofluorescent staining for PC1 and PC2 in paraventricular lateral magnocellular cells (PaLMs), paraventricular medial parvocellular cells (PaMPs), and periventricular parvocellular cells (Figures 5 and 6). The PaMP region shown in Figure 5 demonstrat- reflected in the biosynthesis and PC-dependent processing of proTRH. In an initial examination of proTRH synthesis and processing, we first analyzed the levels of mature TRH in the PVN and ME. Figure 7A depicts a typical distribution of proTRH-derived peptides within the PVN and ME, as determined by IHC. By microdissection of the same regions, we found that the concentrations of TRH in the PVN were reduced by $72 \%$ in fasted animals $(1.8 \pm 12$ $\mathrm{pg} / \mu \mathrm{g}$ protein, $n=6)$ relative to those in the fed state $(6.4 \pm 0.3$ $\mathrm{pg} / \mu \mathrm{g}$ protein, $P<0.001, n=6)$ and that leptin prevented this fall $(7.1 \pm 0.4 \mu \mathrm{g} / \mathrm{mg}$ protein, $P<0.001$ vs. fasted, $n=6)$ (Figure $7 \mathrm{~B})$. In addition, the concentration of immunoreactive TRH in the ME was depressed by $52 \%$ in the fasted animals $(12 \pm 0.2 \mathrm{pg} / \mu \mathrm{g}$ protein, $n=6)$ relative to those in the fed state $(25 \pm 0.3 \mathrm{pg} / \mu \mathrm{g}$ protein, $P<0.001, n=6$ ), and administration of recombinant leptin during the fasting period brought the level of TRH to levels similar to those measured in fed animals $(31 \pm 0.4 \mathrm{pg} / \mu \mathrm{g}$ protein, $P<0.001$ vs. fasting, $n=6$ ) (Figure $7 \mathrm{~B}$ ). Consistent with the decrease in TRH during fasting, the serum concentrations of thyroxine $\left(T_{4}\right)$ and $T_{3}$ decreased seven- and tenfold, respectively, as shown in other studies (46), and levels in fasted animals treated with leptin were comparable to levels in the fed controls (Figure 7C). In addition, TSH levels also decreased during fasting, and systemic administration of leptin prevented this fall (Figure 7C). 
A
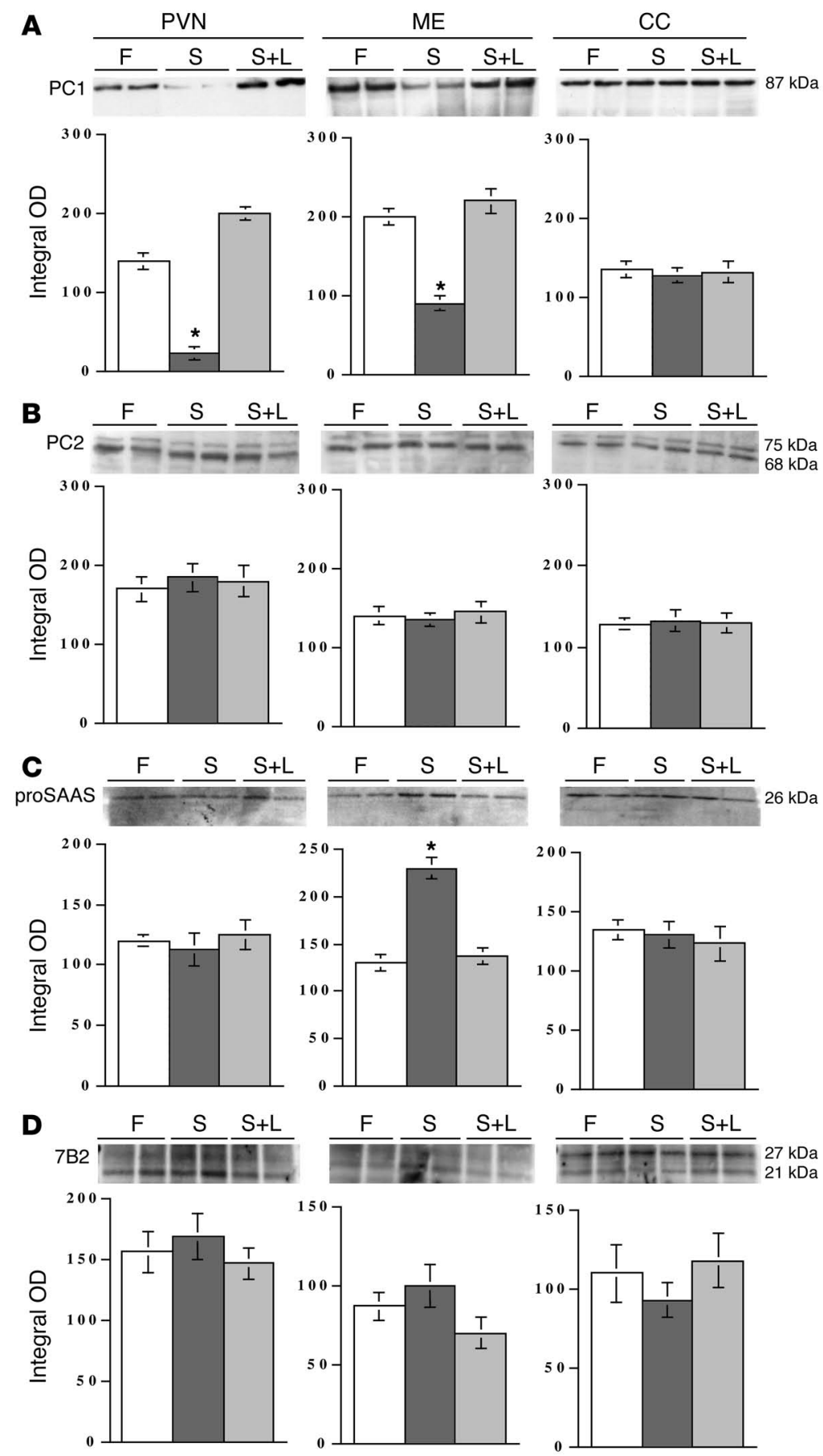

\section{Figure 4}

Analysis of fasting- and leptin-induced regulation of PC1 and $\mathrm{PC} 2$ proteins in the PVN and ME of rats. The upper panels in A-D depict a typical Western blot for PC1, PC2, proSAAS, and 7B2 proteins in fed animals, starved animals, and starved animals that received leptin $(S+L)$. A total of 9 animals per condition were used in this study. The lower panels in $\mathbf{A}-\mathbf{D}$ show the compared integrated optical density using $\mathrm{NIH}$ Image software for PC1 and PC2 in the 3 brain areas analyzed. ANOVA was followed by a multiple comparison using a Tukey-Kramer test. ${ }^{\star} P<0.01$, significant difference at this level. Sixty micrograms of total protein was loaded in each well for each condition. The same electrophoretic mobility for PC1 and PC2 molecular mass is indicated at the far right of the upper panels in $\mathbf{A}$ and $\mathbf{B}$.

ed peptides (Figure 8B). Furthermore, whereas in the fasted animals the $15-\mathrm{kDa}$ and $\mathrm{pEH} 24$ peptides were decreased, the TRH-pEH24 form remained unchanged, which suggests specific alterations in posttranslational processing that are due to changes in the enzymatic activity of the PCs.

Further detailed analyses showed that the femtomole amounts of the 3 forms produced in the PVN and ME were consistently decreased in the fasted state, but that the ratios between specific forms were altered; this indicates a change in processing of proTRH (Tables 1 and 2). For example, fasting reduced proTRH biosynthesis by $50 \%$ as judged by the steady-state amount (in femtomoles) for each moiety in fed versus fasted condition (91.2 total fmol in fed vs. 45.6 total fmol in starved animals). In addition, proTRH processing was also affected, as indicated by the fact that the relative amounts (in percent) of the processing products were substantially altered. In particular, the TRH-pEH24 extended form increased by about $50 \%$ in the fasted group compared with $28.5 \%$ in the fed controls, while the pEH24 peptide decreased under the same conditions (from $61.5 \%$ in the fed state to $41.7 \%$ ). These results strongly suggest that the decrease in PEH24 peptide biosynthesis was a consequence of reduced conversion of TRH-pEH24 into pEH24 by PC enzymes, consistent with the results shown in Figures 1-6. Administration of leptin to fasted animals reconstituted percentage levels of peptides similar to those in the fed state; however, the overall biosynthesis of proTRH only reached $68 \%$ of the $91.2 \mathrm{fmol}$ generated in the control fed animals. This indicates that the processing profile of proTRH in fasted rats was reestablished

The reduced levels of TRH could be due to lower transcription and biosynthesis of proTRH, a deficiency in the processing of the prohormone, or a combination thereof. To clarify this point, we used an antiserum against the preproTRH $\mathrm{H}_{83-106}$ (pEH24) moiety that also recognizes several intermediate forms of proTRH (59) (see schematic drawing in Figure 8A). Specifically, the antiserum detects an early $15-\mathrm{kDa}$ cleavage product, an extended from of the pEH24 peptide, TRH-pEH24 ( $3.8 \mathrm{kDa})$, and pEH24 (2.75 $\mathrm{kDa})$ (7). Separation of these proTRH-derived intermediate forms and end products from the PVN and ME by SDS-PAGE revealed that the TRH precursor was processed into the predictas similar to that in fed animals by leptin treatment. In the ME, we did not detect the TRH-pEH24 extended form, which suggests that the pEH24 peptide is already formed when it reaches the ME. Furthermore, the pEH24 peptide ratio (fed/fast) was dramatically decreased in the fasted animals, consistent with the accumulation of its proform (TRH-pEH24) that was observed in the PVN. The TRH-pEH24 fed/fasted ratio did not change significantly (i.e., 1.1), even though $50 \%$ reduction of the total proTRH biosynthesis was measured. These data again support the hypothesis that a significant reduction of $\mathrm{PC}$ activity occurs during fasting that prevents full formation of the end product of processing, pEH24. 


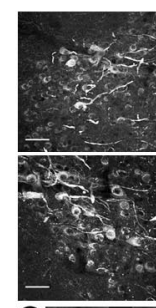

A
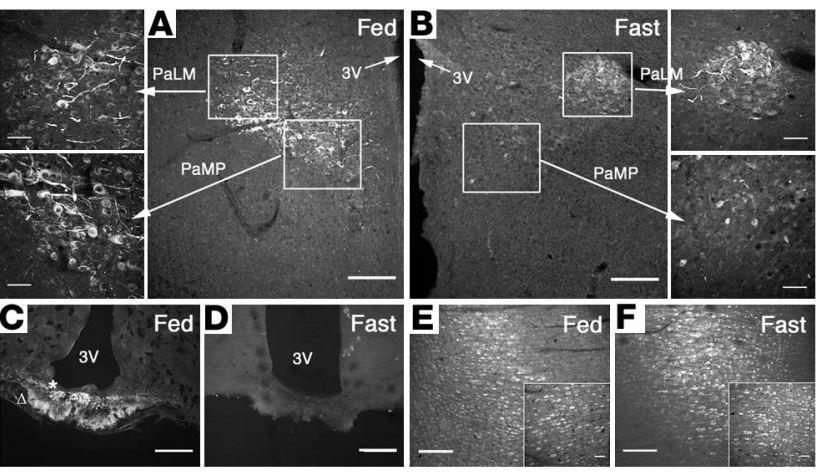

Figure 5

Immunolocalization of PC1 in hypophysiotropic areas of the hypothalamus in fed versus fasting animals. (A and $\mathbf{B}$ ) Typical photomicrographs showing the immunodistribution of PC1 in the PaLMs and the PaMPs. (C and D) The ME. (E and F) The CC. A significant decrease in PC1 immunoreactivity is shown in the PaMPs (the location of hypophysiotropic TRH neurons) from fasted animals (B) as compared with fed controls (A). See also the high-magnification images at the left of $\mathbf{A}$ and the right of $\mathbf{B}$. In the same brain section, the PaLM subdivision, which also expresses PC1, did not change during fasting ( $\mathbf{A}$ and $\mathbf{B}$; see also the high-magnification images). $\mathbf{A}$ and $\mathbf{B}$ show low magnification $(\times 10$, scale bar: $200 \mu \mathrm{m})$. High-magnification images are indicated by arrows ( $\times 40$, scale bar: $50 \mu \mathrm{m})$. The ME region (C and $\mathbf{D})$ shows a strong immunostaining in the internal zone (asterisk) and less intense staining in the external zone (triangle) of the medial portion of the ME in fed animals. Similar changes were observed in the anterior and posterior ME (not shown). The immunoreactivity for PC1 in the CC (E and F) did not show differences between fed and fasted animals (see also insets). $\mathbf{C}-\mathbf{F}$ and insets, $\times 20$, scale bar: $50 \mu \mathrm{m}$. 3v, third ventricle.

\section{Discussion}

In this study we present evidence supporting the hypothesis that the regulation of hypophysiotropic TRH biosynthesis by leptin occurs not only at the transcriptional level, but also at the posttranslational level through changes in proTRH processing by the action of PC1 and PC2. Using in vitro and in vivo approaches, we show strong evidence that leptin regulates PC1 and PC2 expression and protein biosynthesis and that, as a consequence of those regulatory changes, the posttranslational processing of proTRH is affected.

Using primary cultures of hypothalamic neurons, which express leptin receptors, PC1, PC2, and proTRH (10), we demonstrated that leptin treatment increases the mRNA and protein levels of PC1 and PC2. In addition, using a heterologous transfection system, we showed that leptin stimulates PC1 and PC2 promoter activities, supporting the hypothesis of leptin-dependent activation of the PC1 and PC2 genes in leptin receptor-positive neurons. The transfection experiments as well as the demonstration of leptin-induced STAT3 phosphorylation in TRH neurons of rats also suggest that the STAT3 transcription factor is required for this regulation. The mechanism by which STAT3 regulates the PC1 and PC2 promoters is unknown at this time, but we speculate that STAT3 may bind directly to STAT3-responsive DNA elements located in proximal regions of the 2 promoters, although no functional role has yet been reported in these genes. However, regulation of the PC1 promoter by leukemia-inhibitory factor (LIF), a cytokine, which, like leptin, uses the JAK-STAT intracellular signaling system (60), has been shown, although the signaling mechanisms remain unknown. Alternatively, the effect could be mediated indirectly by regulation of other transcription factors acting on the PC1 and PC2 promoters. Known regulators of PC1 expression include cAMP, as 2 cAMP-responsive elements have been reported in the proximal PC1 promoter (60). However, since leptin receptors are not believed to signal via cAMP, this pathway is unlikely to play a role in the regulation of PC1 expression by leptin. The PC2 promoter has been shown to contain 2 binding sites for the transcription factor EGR-1, and coexpression of EGR-1 in transfected cells increases transcription of the PC2 promoter (61). Leptin does stimulate egr-1 gene expression in vitro (62), and it is therefore possible that EGR-1 could mediate some effects of leptin on the PC2 promoter. However, since leptin-induced egr-1 expression appears to be regulated via the ERK pathway, and not by the STAT3 pathway, further promoter studies are clearly needed to determine the intracellular mechanisms by which leptin regulates PC1 and PC2 promoter activities and in which cells this regulation might occur in vivo. The consensus STAT3 response element is CTGG(G)AA (63). In the PC1 promoter there is a STAT3 response element (CTGGGAA) at positions -226 to -220 , while there is no consensus STAT3 response element in the proximal region of the PC2 promoter. This is consistent with our findings in Figure 2A, that leptin stimulated PC1 promoter activity much more than PC2 promoter activity in the presence of STAT3 transfection. However, a putative STAT3 binding site $(-231 /-331)$ can be identified in the PC2 promoter using computer software. Further gel-shift studies from leptin-stimulated cells that express STAT3 will be needed to examine this possibility.

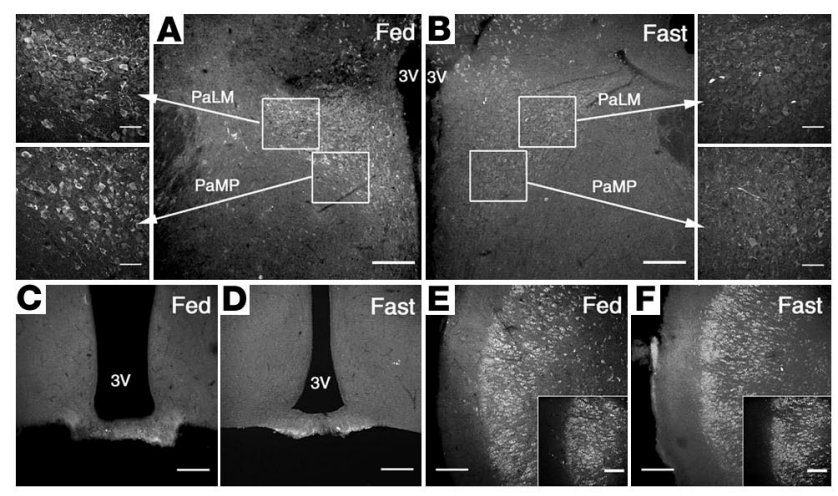

\section{Figure 6}

Immunolocalization of PC2 in hypophysiotropic areas of the hypothalamus during fed versus fasted states. (A and B) Typical photomicrographs showing the immunodistribution of PC2 in the PaLMs and the PaMPs. (C and $\mathbf{D})$ The ME. (E and F) The CC. A significant decrease in PC2 immunoreactivity is shown in the PaMPs (the location of hypophysiotropic TRH neurons) from fasted animals (B) as compared with fed controls (A). See also the high-magnification images at the left of $\mathbf{A}$ and the right of $\mathbf{B}$. In the same brain section, the PaLM subdivision, which also expresses $\mathrm{PC}$, showed a decrease during fasting (A and $\mathbf{B}$; see also the high-magnification images). $\mathbf{A}$ and $\mathbf{B}$ show low magnification $(\times 10$, scale bar: $200 \mu \mathrm{m})$. High-magnification images are indicated by arrows ( $\times 40$, scale bar: $50 \mu \mathrm{m})$. The ME region (C and $\mathbf{D})$ shows a weak, unchanged immunostaining in the internal zone and less intense staining in the external zone of the medial portion of the ME in fed as compared with fasted animals. No changes were observed in the anterior and posterior ME (not shown). The immunoreactivity for PC2 in the $\mathrm{CC}(\mathbf{E}$ and $\mathbf{F})$ did not show differences between fed and fasted animals (see also insets). Magnification in E and F, ×20; scale bar: $50 \mu \mathrm{m}$. 
A
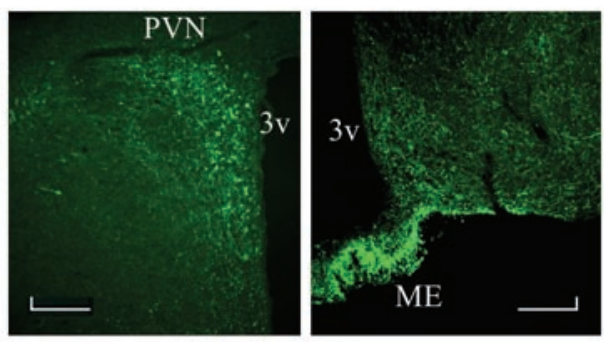

B
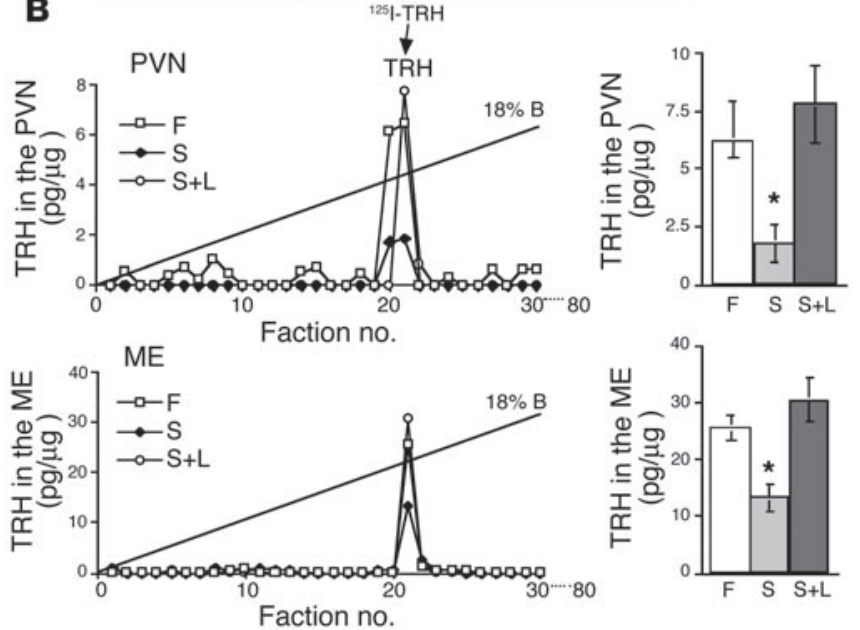

c
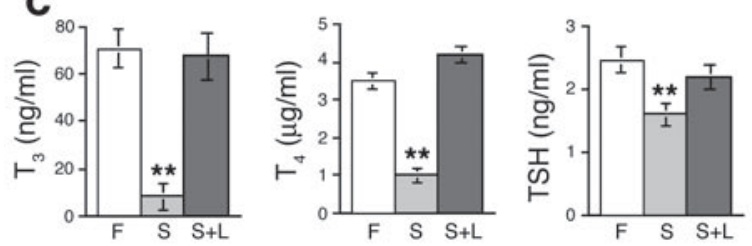

In another system regulating the PCs, recent findings suggest that thyroid hormone receptor action can negatively regulate PC1 and PC2 gene expression in the pituitary via thyroid hormone response elements present in the promoters $(64,65)$. It is, however, unknown whether such downregulation of PC expression by thyroid hormones occurs in different regions of the hypothalamus. Thyroid hormone receptors are expressed in the hypothalamus, including in the hypophysiotrophic TRH neurons, where they act in a feedback loop to negatively regulate TRH gene expression. It seems unlikely that conditions of low $\mathrm{T}_{3}$ and $\mathrm{T}_{4}$ levels, as during fasting, would lead to upregulation of PC1 and PC2 in the TRH neurons, since this state is associated with low expression levels of the TRH precursor. On the other hand, in the arcuate nucleus of the hypothalamus, PC1 and PC2 are believed to play a role in

\section{Figure 7}

Leptin regulates the biosynthesis of the $\mathrm{TRH}$ peptide. (A) A typical IHC photomicrograph showing the immunodistribution of proTRH-derived peptides in the PVN and the ME. (B) HPLC separation of PVN and ME protein samples extracted from fed, fasted, and fasted-plus-leptin animals was followed by a specific TRH RIA assay in each fraction collected. Each representative chromatogram displays the elution positions of the synthetic TRH standard. Recoveries were about 95\%, and each data point was replicated 3 times. A total of 6 animals per condition were used in this study. ANOVA was followed by a multiple comparison using a Tukey-Kramer test. ${ }^{*} P<0.01$, significant difference at this level. (C) The comparative values of $\mathrm{T}_{3}, \mathrm{~T}_{4}$, and TSH from 20 animals used in each condition. ANOVA was followed by a multiple comparison using a Tukey-Kramer test. ${ }^{* \star} P<0.001$, significant difference at this level.

the processing of proNPY into the mature neuropeptide (27), and fasting is associated with upregulation of neuropeptide Y (NPY) gene expression (66). Therefore, upregulation of PC1 and PC2 expression in NPY neurons, due to a fall in $\mathrm{T}_{3}$ levels during negative energy balance, may be possible. Altogether, it seems worthy to test these hypotheses and to examine the possible regulation of PC expression by leptin within specific neuronal groups of the brain.

In the physiological model of starvation, a state of low leptin levels, we demonstrated that in the PVN and the ME the level of PC1 was decreased. PC activity in the ME is very important, since this is an essential region where fully or partially processed hypophysiotrophic hormones converge before they release their products into the fenestrated endothelium of the portal capillaries. Exogenous administration of leptin to fasted animals raised the level of PC1 in the PVN as well as in the ME to approximately the levels found in the fed control animals. Altogether, the in vitro and in vivo experiments strongly support an active role for leptin in the fate of PC1 in specific hypothalamic nuclei, which are important for the regulation of energy balance. Interestingly, we did not detect any changes in PC2 in the PVN or ME while using this microdissection approach, although in vitro studies suggested regulation of PC2 by leptin. This lack of change was further clarified by examination, using an IHC protocol, of specific regions of the hypothalamus, where we found a substantial decrease of PC2 in the PaMPs in fasted animals as compared with fed controls. The IHC data further confirmed the decrease of PC1 in the PaMPs and a dramatic decrease of the enzyme in the ME during fasting.

While fasting reduces the expression and protein levels of PC1 and PC2 in the PaMPs, other areas not related to hypophysiotropic TRH neurons, such as the PaLMs, did not change for PC1 but showed some decrease in PC2. The CC showed no changes in PC1 and PC2, nor did the nucleus reuniens of the midline thalamus, which contains PC2 but not PC1. The dorsomedial nucleus, which is well rec-

Table 1

Distribution of proTRH-derived peptides in the PVN during fasting as compared with the fed state

\begin{tabular}{|c|c|c|c|c|c|c|c|c|}
\hline \multirow[t]{2}{*}{ ProTRH products } & \multicolumn{2}{|c|}{ Fed } & \multicolumn{2}{|c|}{ Fasted } & \multicolumn{2}{|c|}{ Fasted + leptin } & \multirow[b]{2}{*}{ Fed/fasted (MR $\left.{ }^{B}\right)$} & \multirow[b]{2}{*}{ Fed/fasted + leptin (MR } \\
\hline & fmol & Percent ${ }^{A}$ & fmol & Percent & fmol & Percent & & \\
\hline $15-\mathrm{kDa}$ form & 9.2 & 10.0 & 3.6 & 7.9 & 7.6 & 12.2 & 2.5 & 1.2 \\
\hline TRH-pEH24 & 26.0 & 28.5 & 23.0 & 50.4 & 15.3 & 24.6 & 1.1 & 1.7 \\
\hline pEH24 & 56.0 & 61.5 & 19.0 & 41.7 & 39.2 & 63.2 & 2.9 & 1.4 \\
\hline Total & 91.2 & 100 & 45.6 & 100 & 62.1 & 100 & & \\
\hline
\end{tabular}

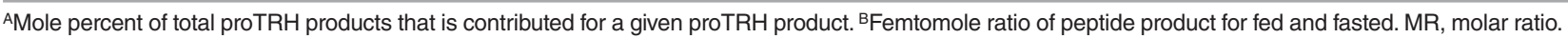



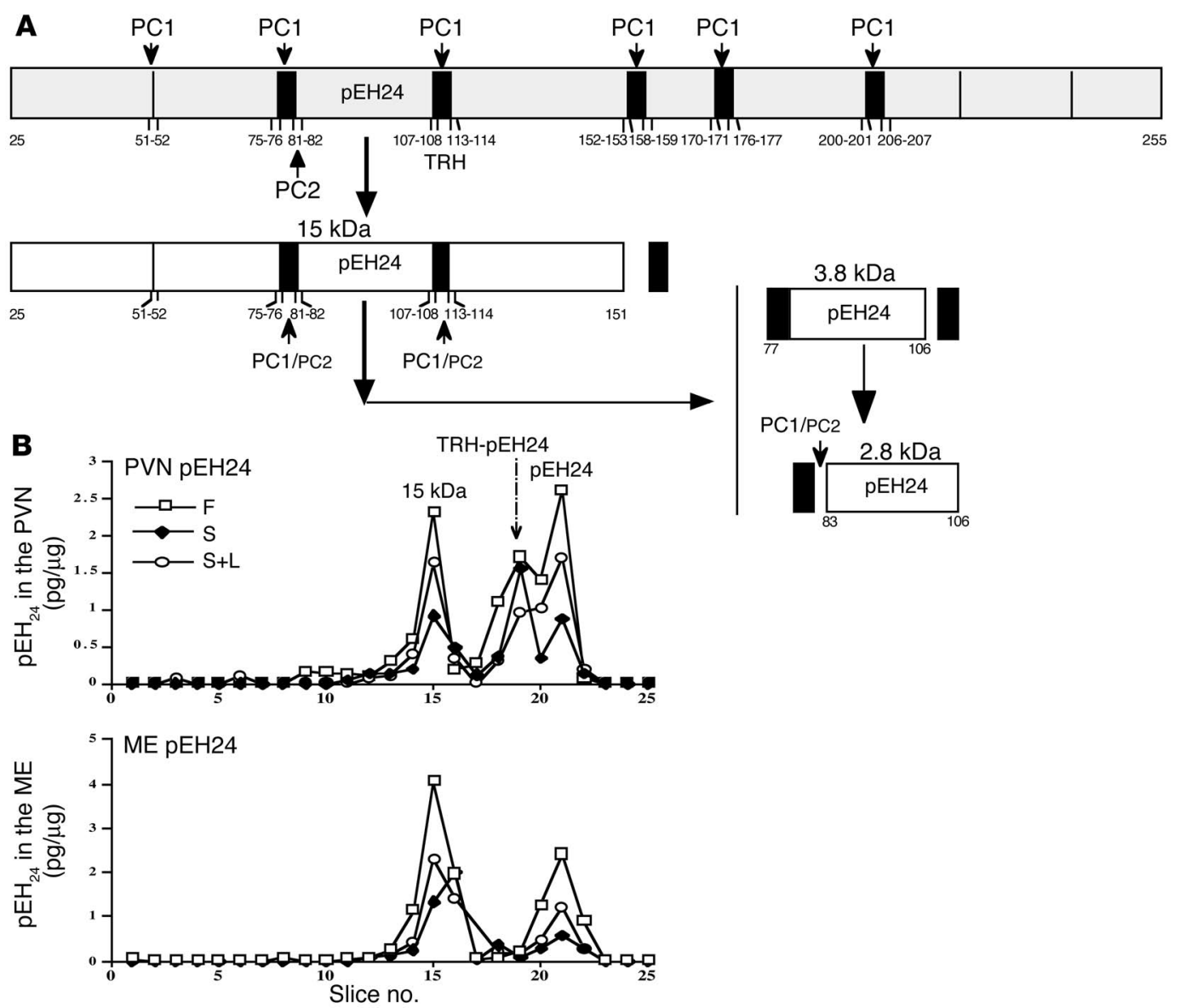

Figure 8

Fasting alters the posttranslational processing of proTRH. The scheme in A represents a portion of the original processing model for proTRH, where the formation of $\mathrm{N}$-terminal peptide 24 is indicated by the action of PC1 and PC2. The small arrows indicate the sites where PC1 and PC2 produce their enzymatic cleavages. The size of PC1 and PC2 lettering indicates relative activity at a given site. Large arrows indicate the order of processing. (B) An electrophoretic separation on a Tricine SDS-polyacrylamide gel of PVN and ME samples extracted from fed, fasted, and fastedplus-leptin animals was followed by acid extraction of gel slices and RIA against pEH24 peptide. This RIA recognizes $3 \mathrm{~N}$-terminal moieties derived from proTRH processing, the 15-, 3.8-, and 2.8-kDa (pEH24) forms depicted in A. Molecular masses of the identified peaks are indicated based on the migration of standards and iodinated synthetic $\mathrm{pEH} 24$ peptide. These figures represent a typical profile of 3 independent experiments.

ognized for its role in neuroendocrine and autonomic homeostasis and is well known to have PC2 but not PC1 and to have a high concentration of leptin receptor (67), showed changes in PC2 (not shown). Together these data suggest that the physiological condition of fasting (low leptin) affects the expression and protein synthesis of PC1 and PC2 in a brain region-specific manner. In further analysis of the levels of proSAAS and 7B2 during starvation, we found that, in the ME, proSAAS protein levels increased during fasting (Figure 4C), indicating that decreased levels of leptin may result in lower levels of PC1 through decreased transcription and possibly in decreased PC1 enzyme activity through inhibition by the proSAAS peptide. In the PVN, leptin regulation of PC1 activity appears to occur strictly through regulation of the PC1 promoter. The results also suggest that $7 \mathrm{~B} 2$ peptide does not participate in this regulation. It is important to note that these results are based on Western blot analysis, and the changes in 7B2 during fasting might be represented in only a small subpopulation of neurons. Similar types of observations are described for PC2 in Figure 4B and Figure 6, A and B.

Our data showing alteration in PC1 and PC2 mRNA/protein levels due to changes in leptin levels were also reflected in the analysis of the biosynthesis of proTRH and its further processing into TRH and other proTRH-derived peptides. Rat preproTRH (a 29-kDa polypeptide composed of 255 amino acids) is processed, primarily by PC1 and secondarily by PC2, in a complex series of steps at specific sites in the secretory pathway $(6,7,68)$. This precursor contains an $\mathrm{N}$-terminal 25 -amino acid leader sequence followed by an N-terminal flanking peptide, 5 copies of the TRH progenitor sequence Gln-His-Pro-Gly flanked by paired basic amino acids (Lys-Arg or Arg-Arg), 4 non-TRH peptides lying between the TRH progenitors, and a C-terminal flanking peptide (6). The N-terminal flanking peptide (preproTRH $\mathrm{T}_{25-50}-\mathrm{R}-\mathrm{R}$-preproTRH $\mathrm{T}_{5-74}$ ) is further cleaved at the $\mathrm{C}$-terminal side of the paired arginine residues to give preproTRH $\mathrm{H}_{25-50}$ and preproTRH $\mathrm{H}_{53-74}$, thus yielding a total of 7 proTRH-derived peptides. The amount of the TRH peptide detected in fed animals was fivefold higher in the ME than in the PVN, indicating, as expected, that the majority of mature peptides are present in mature granules near the axon terminals, ready for release to the circulation. During fasting, the level of TRH peptide fell approximately $72 \%$ and $52 \%$ in the PVN and ME, respectively. The TRH levels were restored when the animals received systemic 
Table 2

Distribution of proTRH-derived peptides in the ME during fasting as compared with the fed state

\begin{tabular}{|c|c|c|c|c|c|c|c|c|}
\hline \multirow[t]{2}{*}{ ProTRH products } & \multicolumn{2}{|c|}{ Fed } & \multicolumn{2}{|c|}{ Fasted } & \multicolumn{2}{|c|}{ Fasted + leptin } & \multirow[b]{2}{*}{ Fed/fasted (MR $\left.{ }^{B}\right)$} & \multirow[b]{2}{*}{ Fed/fasted + leptin $\left(M^{B}\right)$} \\
\hline & fmol & Percent $^{A}$ & fmol & Percent & fmol & Percent & & \\
\hline 15-kDa form & 14.0 & 22.5 & 7.3 & 38 & 8.4 & 26.7 & 1.9 & 1.7 \\
\hline pEH24 & 48.0 & 77.5 & 11.9 & 62 & 23.0 & 73.3 & 4.0 & 2.0 \\
\hline Total & 62 & 100 & 19.2 & 100 & 31.4 & 100 & & \\
\hline
\end{tabular}

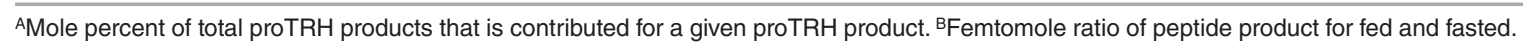

administration of leptin. Analysis of the proTRH processing indicated that the amounts of precursor peptide in the fasted condition decreased, and the processing products displayed a pattern different from that seen in the fed state (Tables 1 and 2). Fasting not only caused a reduction in the gene expression of proTRH that was reflected in a $50 \%$ reduction in proTRH biosynthesis, but also affected proTRH processing. Collectively, these data indicate that processing of proTRH changed in the PVN of fasted animals.

Changes in the processing of proTRH have also been observed previously under other physiological conditions. During opiate withdrawal in rats, for example, preproTRH mRNA is induced in the periaqueductal gray (PAG), and the $\mathrm{N}$-terminal peptides preproTRH $_{53-74}$ and pEH24 are increased, whereas the level of TRH remains unaltered (69-71). In addition, the mature form of PC2 was seen to increase in the PAG of animals subjected to opiate withdrawal. Thus, these results demonstrate a region-specific regulation of proTRH processing in the brain, which may involve PC2, further suggesting a role for specific proTRH-derived peptides in the manifestations of opiate withdrawal (69). The pFE22 C-terminal peptide and its processed forms are increased in the PVN during suckling as a result of changes in proTRH processing (68). As an adaptive response to increase body temperature, cold exposure is also associated with increased expression of preproTRH in hypophysiotropic neurons and, in turn, increased secretion of TSH and a subsequent increase in thyroid hormone levels (72). In studies with the Cpe fat mouse, we demonstrated that the Cpe efat mutation might affect TRH biosynthesis and that it caused aberrant proTRH processing (38); this suggests that various products derived from proTRH can be independently regulated under altered physiological conditions. Interestingly, genetically obese (ob/ob) mice exposed to a cold environment showed a low increase in brown adipose tissue thermogenesis, a delayed increase in thyroxine $5^{\prime}$-deiodinase, and a reduced increase in serum $T_{3}$ level, and these mice became hypothermic ( 73 , 74). This seems to suggest that leptin is important in the thermoregulatory process during cold stress.

The physiological evidence that fasting affected the HPT axis by decreasing $T_{3}$ and $T_{4}$ was previously described (46). We found that systemic administration of leptin to the fasted animals prevented this decrease, as was reported by others (46). After leptin treatment, the $T_{4}$ values exceeded the normal values in fed animals. The TSH levels, consistent with previous studies (42), showed a small, but significant, decrease in male rats during fasting. It is has been previously suggested that most of the TSH detected during fasting, in the absence of TRH, may not be functional. TRH plays a key role in the glycosylation of TSH, which means that such a reduction in TRH leads to TSH with less complex carbohydrate structures and reduced bioactivity that can be restored by TRH administration (42). Interestingly, humans with central hypothy- roidism frequently have normal, or even slightly higher, serum TSH concentrations. Again, consistent with this fall in pituitary and thyroid hormones, a reduction in preproTRH mRNA in the PVN was observed. The preproTRH mRNA expression was shown to be restored after leptin treatment. A similar, clinical study in humans was consistent with our own findings. The authors of that study (75) found that maintenance of reduced body weight was associated with a decrease in 24-hour energy expenditure and a decrease in circulating plasma concentrations of leptin and thyroid hormones. All these endocrine changes were reversed by administration of replacement doses of leptin. The data support the hypothesis that the neuroendocrine changes associated with constant reduced body weight are due, partially, to the lower circulating levels of leptin secondary to reduced fat mass. In recent studies, it was reported that TRH induces hypertension in the normal rat and that spontaneously hypertensive rats have central TRH hyperactivity with increased TRH synthesis and release and an elevated number of TRH receptors $(76,77)$. The same group suggests that in rats with TRH-induced hypertension, leptin is decreased, which leads to compensatory adiposity. They propose that because leptin stimulates central TRH synthesis and release, obesity may induce hypertension through TRH system activation, and that the TRH-leptin interaction may thus contribute to the strong association between hypertension and obesity $(76,77)$.

Thus, our results demonstrate that leptin upregulates expression and protein biosynthesis of preproTRH, and that this regulation is coupled with coordinated upregulation of the processing enzymes. We hypothesize that such regulation ultimately leads to more effective processing of leptin-regulated proneuropeptides into mature peptides, such as TRH and $\alpha-\mathrm{MSH}$, which are believed to be critical for leptin action. Transcriptional control of PC1 and PC2 gene expression by leptin is another level at which this hormone regulates energy homeostasis. Overall, this study demonstrates that processing of proTRH, and the subsequent secretion of TRH in the ME to stimulate the HPT axis, constitute an additional key checkpoint that is tightly regulated to control energy consumption. The relationship between the regulatory effect of leptin on the PCs and proTRH, and the effect of PCs on proTRH, will substantially improve our understanding of how leptin affects transcriptional and posttranslational activity in a coordinated fashion in proTRH and other proneuropeptides including POMC, NPY, and CART. Identification of the mechanisms by which these coordinated regulations are controlled could ultimately suggest novel therapeutic strategies for the treatment of obesity and other diseases related to the thyroid axis.

\section{Methods}

Materials. Recombinant mouse leptin was obtained from A.F. Parlow (Harbor-University of California at Los Angeles Medical Center, Torrance, 
California, USA). The expression vector encoding the long murine leptin receptor was generated as described earlier (51). S. Melmed (Cedars-Sinai Medical Center, Los Angeles, California, USA) and T. Hirano (Osaka University, Osaka, Japan) provided the wild-type STAT3 and dominant negative Y705F-STAT3 expression vectors. The human PC1 (-971 to -1 bp; numbering relative to the translation start site) and human PC2 (-789 to $-1 \mathrm{bp}$ ) promoter-luciferase plasmids (cloned into pGL-2 from Promega Corp., Madison, Wisconsin, USA) were supplied by E. Jansen (University of Leuven, Leuven, Belgium). The CMV-lacZ control plasmid encoding $\beta$-galactosidase was purchased from BD Biosciences - Clontech (Palo Alto, California, USA). Rat PC1 and PC2 cDNA plasmids are reagents that have been established in our laboratory, and mouse GAPDH cDNA was obtained from BD Biosciences - Clontech. Nabil Seidah (Clinical Research Institute of Montreal, Montreal, Quebec, Canada) donated the antibodies against PC1 and PC2. Lloyd Fricker (Albert Einstein College of Medicine, New York, New York, USA) donated the antibodies against proSAAS. Iris Lindberg (Louisiana State University, Baton Rouge, Louisiana, USA) donated the antibodies against pro7B2.

Animals for primary cultures and in vivo studies. Hypothalamic RNA for quantitative RT-PCR experiments was obtained from male Sprague-Dawley rats (175-225 g), which were purchased from Charles River Laboratories Inc. (Wilmington, Massachusetts, USA). Rats were deeply anesthetized by injection of pentobarbital and then decapitated. The skull was then removed from the brain, and the hypothalamus was isolated with a razor blade and snap-frozen in liquid nitrogen until further analysis.

For primary hypothalamic neurons, timed-pregnant female SpragueDawley rats were purchased from Charles River Laboratories Inc. Hypothalamic neuronal cultures were produced as previously described (47). In brief, timed-pregnant female rats on day 17 of gestation were anesthetized with pentobarbital $(60 \mathrm{mg} / \mathrm{kg}$ ), the abdominal cavity was opened, and the fetuses were removed. Each fetus was decapitated, and the diencephalon was isolated. Diencephalic tissue was dissociated to single cells by neutral protease digestion (1 unit per tissue; Sigma-Aldrich, St. Louis, Missouri, USA). The cells were cultured for up to 14 days in DMEM/L-15 (78) containing 10\% FCS (Invitrogen, Carlsbad, California, USA) and supplemented with various additives previously described (47). Prior to plating, all 6-well plates and Lab-Teks (Nalge Nunc International, Naperville, Illinois, USA) were coated with $20 \mu \mathrm{g} / \mathrm{ml}$ of poly-D-lysine (Sigma-Aldrich). For immunocytochemistry, the cells were plated on 4-chamber glass Lab-Tek slides $\left(10^{6} \mathrm{cells} / \mathrm{ml}\right)$. For protein and gene expression experiments, the cells were incubated in $100-\mathrm{cm}^{2}$ flasks $\left(5 \times 10^{6}\right.$ to $6 \times 10^{6}$ cells per flask).

For in vivo studies, male Sprague-Dawley rats weighing 150-175 g were acclimatized to a 12-hour light/12-hour dark cycle (lights on between 0600 and 1800 hours) and controlled temperature $\left(22^{\circ} \mathrm{C} \pm 1{ }^{\circ} \mathrm{C}\right)$ before the procedures. Rat chow and tap water were provided ad libitum. Animals were divided into 3 groups - fed; fasted; and fasted and injected with leptin - with 3 animals in each group. The first group was allowed free access to food and water. The second group was fasted for 65 hours, beginning at 1600 hours the first day and ending between 0900 and 1100 hours on the third day. However, this group was allowed continued access to drinking water. The third group was fasted as described above, but $0.5 \mu \mathrm{g} / \mathrm{g}$ body weight of recombinant leptin was administered intraperitoneally every 6 hours beginning 2 hours after the removal of food. All animals were weighed daily and, at completion of the experiment, were anesthetized with pentobarbital ( $60 \mathrm{mg} / \mathrm{kg}$ body weight intraperitoneally). Blood was obtained from the inferior vena cava for measurement of the serum thyroid hormones $\mathrm{T}_{3}$ and $\mathrm{T}_{4}$. After removal of the skull, different brain regions were collected for peptide-content analysis.

For brain fixation and tissue preparation, 6 fasted ( 65 hours) and 6 fed adult male Sprague-Dawley rats (Charles River Laboratories Inc.) were deeply anes- thetized with sodium pentobarbital (60 $\mathrm{mg} / \mathrm{kg}$ intraperitoneally), perfused transcardially (69) with saline solution $(0.9 \% \mathrm{NaCl})$, and fixed with $4 \%$ paraformaldehyde in $0.1 \mathrm{M}$ phosphate buffer ( $\mathrm{pH}$ 7.4). Brains were removed and postfixed in the same fixative for 2 hours and cryoprotected by overnight immersion in a solution containing $20 \%$ sucrose in $0.1 \mathrm{M}$ phosphate buffer. Twenty-micrometer transverse tissue sections were cut using a cryostat, and mounted on glass slides for IHC. The experimental protocols and euthanasia procedures were reviewed and approved by the Institutional Animal Care and Use Committee of Rhode Island Hospital/Brown University.

Immunohistochemistry. Cryostat sections from fasted and fed animals were processed for PC1 and PC2 immunofluorescence using either anti-PC1 or anti-PC2 rabbit polyclonal antibodies (both C-terminal site-directed antisera) $(19,20,79)$. Briefly, sections were rinsed in $0.1 \mathrm{M}$ Tris-buffered saline ( $\mathrm{pH} 7.4$ ) containing $0.05 \%$ Tween- 20 (TBST) and preincubated for 30 minutes in $0.1 \mathrm{M}$ Tris-buffered saline ( $\mathrm{pH} 7.4$ ) (TBS) containing $3 \%$ normal goat serum (NGS). Sections were then incubated for 48 hours at $4{ }^{\circ} \mathrm{C}$ in $0.1 \mathrm{M}$ TBS containing $0.5 \% \mathrm{NGS}, 0.3 \%$ Tween-20, and $1: 1,000 \mathrm{PC} 1$ or 1:8,000 PC2 antibodies. Sections were subsequently rinsed in TBST and incubated for an hour with Alexa Fluor 594 goat anti-rabbit IgG (Molecular Probes Inc., Eugene, Oregon, USA) diluted 1:400 in 0.1 M TBS, 3\% NGS. Sections were then rinsed several times in $0.1 \mathrm{M}$ TBST and coverslipped with VECTASHIELD solution (Vector Laboratories Inc., Burlingame, California, USA). Gray-scale images (12-bit) were acquired with a Nikon E800 microscope (Nikon Inc., Melville, New York, USA). Images were captured with a SPOT II digital camera (Diagnostic Instruments, Sterling Heights, Michigan, USA) using the built-in green filter to increase image contrast. Confocal images were acquired with a Nikon PCM 2000 (Nikon Inc.) using the green helium-neon laser $(543 \mathrm{~nm})$. Serial optical sections were performed with Simple $32 \mathrm{C}$-imaging computer software (Compix Inc., Tualatin, Oregon, USA). Z-series sections were collected at $1 \mu \mathrm{m}$ with a $\times 40$ Plan Apo lens or a $\times 10$ Plan Apo lens (Panasonic, Secaucus, New Jersey, USA). A scan zoom of $\times 1$ was used in the acquisition of images. Images were processed and reconstructed in NIH Image shareware $\mathrm{NIH}$, Springfield, Virginia, USA). Adobe Photoshop was used for the assembly of figures (Adobe Systems Inc., San Jose, California, USA).

Double immunohistochemistry for TRH and P-STAT3 was done as we have earlier described in detail (54). Briefly, $25-\mu \mathrm{m}$-thick coronal sections were cut on a sliding microtome from formalin-fixed brains. The P-STAT3 antibody was used at 1:3,000 and detected with a biotinylated secondary antibody giving a brown precipitate (ABC system; Vector Laboratories Inc.). Consecutively, IHC for TRH was performed using a primary anti-proTRH antiserum $(1: 50,000)$ and a fluorescent secondary antibody generating green fluorescence. Results were visualized using either a fluorescence source or a bright-field light source (for TRH or P-STAT3, respectively) and captured with a digital camera (AxioCam; Carl Zeiss Inc., Thornwood, New York, USA) mounted on a Zeiss microscope (Axioscope 2; Carl Zeiss Inc.). Using Adobe Photoshop software, fluorescence and bright-field photographs were combined using red-green-blue channels to visualize double-labeled cells.

Quantification of PC1 and PC2 $m R$ NA by quantitative RT-PCR and Northern blot. For Northern blotting, total RNA was isolated from primary cell cultures by acid guanidinium-phenol-chloroform extraction (80). Equal amounts of total RNA were separated in a $1.0 \%$ agarose/formaldehyde gel, blotted onto a nylon filter, and hybridized according to published methods (81) in 5.0\% SDS at $65^{\circ} \mathrm{C}$ for 15 hours. Filters were washed 3 times in $2 \times \mathrm{SSC} / 0.1 \% \mathrm{SDS}$, washed once for 1 hour at $65^{\circ} \mathrm{C}$ in $0.1 \times \mathrm{SSC} / 0.1 \% \mathrm{SDS}$, and then exposed to a PhosphorImager screen for digitized data collection and analysis. Filters were stripped in $1.0 \%$ glycerol at $80^{\circ} \mathrm{C}$ for 5 minutes between hybridizations. The hybridization probes were rat PC1 and PC2 and mouse GAPDH cDNA. Probes were labeled with $\alpha-{ }^{32} \mathrm{P}-\mathrm{dCTP}$ using a random-priming kit (Roche Diagnostics Corp., Indianapolis, Indiana, USA). 
For RT-PCR analysis, total RNA purification and subsequent cDNA synthesis were done in parallel from all samples. Preliminary PCR experiments showed that the rate of amplification was linear for PC1 and PC2 CDNA with less than 27 PCR cycles. We chose 25 cycles for the PCR quantification. We used 17 cycles to amplify $\beta$-actin cDNA. The following primers were used for specific PCR amplification of PC1 and PC2 cDNA: PC1-5', 5'-CGAAGAGGCAGTTTGTCAATGAATGG-3', and PC1-3' $3^{\prime}$-ATCATCAGATAACCTCTTAGTG-3' (200-bp product); PC2-5', 5'-CCTTTGCAGAAGGCCTGTACCAC-3', and PC2-3', 5'-AGCCCAGGAGTCCCGTCAGCTTGC-3' (250-bp product). For amplification of $764 \mathrm{bp}$ of rat $\beta$-actin $\mathrm{cDNA}$, the following primers were used: $5^{\prime}$ primer, $5^{\prime}$-TTGTAACCAACTGGGACGATATGG-3', and $3^{\prime}$ primer, $5^{\prime}$-GATCTTGATCTTCATGGTGCTAGG-3'. Each PCR reaction was incubated with $1.0 \mu \mathrm{l}$ of $\alpha{ }^{-32} \mathrm{P}-\mathrm{dCTP}(29.6 \mathrm{TBq} / \mathrm{mmol}, 370 \mathrm{MBq} /$ $\mathrm{ml}$ ) (PerkinElmer Life and Analytical Sciences, Torrance, California, USA). Ten microliters of the amplified samples were subjected to acrylamide gel electrophoresis. Gels were then transferred to filter paper, dried, and subjected to ${ }^{32} \mathrm{P}$ quantification by PhosphorImager analysis.

Cell culture, transfection, and promoter activity assays. Mouse kidney 293T cells were grown in DMEM supplemented with $10 \%$ FCS, $100 \mathrm{U} / \mathrm{ml}$ penicillin, and $10 \mu \mathrm{g} / \mathrm{ml}$ streptomycin at $37^{\circ} \mathrm{C}$ in $5 \% \mathrm{CO}_{2}$. Cells were transfected with LipofectAMINE according to the recommendations of the manufacturer (Invitrogen Life Technologies). All reagents for cell culture and transfection were from Invitrogen Life Technologies. Cells were serum-deprived for 1215 hours prior to addition of hormones. After cell lysis, aliquots were used for luciferase assay. Briefly, luciferin (Molecular Probes Inc.) and assay buffer were injected simultaneously and measured by a luminometer (EG\&G Berthold, Bad Wildbad, Germany). $\beta$-Galactosidase activities from the same lysates were determined using Galacton (Tropix Inc., Bedford, Massachusetts, USA) and also measured by the luminometer.

Western blot analysis. Fifty micrograms of total protein samples extracted from tissue culture experiments and $25 \mu \mathrm{g}$ extracted from different brain regions were applied onto $8 \%$ glycine-SDS-PAGE gels (standard Laemmli formulation). Following electrophoresis, proteins were electroblotted onto PVDF membranes (Millipore Corp., Billerica, Massachusetts, USA) for immunodetection. The membranes were probed overnight at $4{ }^{\circ} \mathrm{C}$ with a 1:5,000 dilution of anti-PC1 and anti-PC2 antiserum as previously described (7). An alkaline phosphatase-linked goat anti-rabbit Ig secondary antibody (1:2,000 final dilution) was used, and immunoreactive bands were visualized by Immunoblot Kit as described by the manufacturer (BioRad Laboratories, Richmond, California, USA).

HPLC fractionation. A Varian ProStar gradient HPLC system equipped with a C18 reverse-phase column (MicroSorb MV 300-5; Varian Inc., Palo Alto, California, USA) was used to fractionate the tissue samples. ProTRH peptides were eluted using a linear gradient from $0-80 \% \mathrm{~B}$ in 40 minutes using the following mobile phases: (a) $0 \%$ acetonitrile $/ 0.1 \%$ trifluoracetic acid and (b) $90 \%$ acetonitrile/ $0.1 \%$ trifluoracetic acid. The flow rate was 1.0 $\mathrm{ml} / \mathrm{min}$, and there were equilibration times used on either side of the gradient. Fractions $(0.5 \mathrm{ml})$ were collected over the entire 40 -minute gradient. These fractions were then evaporated using an ultracold speed vacuum system and reconstituted in $0.5 \mathrm{ml}$ of the buffer used in the RIA (see below).
Synthetic peptides were subjected to HPLC fractionation to determine retention times. Predicted retention times allowed for analysis of specific regions along the gradient for RIA analysis.

RIA analysis. The assays used for proTRH-derived peptides were developed in our laboratory using commercially synthesized or standard available peptides and primary antibodies (24). The trace was iodinated using the chloramine $\mathrm{T}$ oxidation-reduction method followed by HPLC purification (24). The N-terminal antiserum anti-pEH24, which was used to study proTRH processing $(6,82)$, and TRH $(7,24)$ RIAs were performed as standard in our laboratory. All RIAs were performed on the same volume of material, in duplicate. The intra- and interassay variabilities were 5-6\% and 9-12\%, respectively. Synthetic pEH24 and TRH peptides (Peninsula Laboratories Inc., Belmont, California, USA) were iodinated by the chloramine T method, and the RIAs were performed as previously described (24).

The RIA to measure mouse TSH was developed by A.F. Parlow (HarborUniversity of California at Los Angeles Medical Center). Briefly, standards (0.195-50 ng rat TSH) and serum samples were added in a volume of 0.2 $\mathrm{ml}$ and were incubated with $0.1 \mathrm{ml}$ of guinea pig anti-mouse TSH serum (1:8,000 dilution) for 24 hours at $4^{\circ} \mathrm{C}$. The next day, $2 \%$ normal guinea pig serum (Antibodies Inc., Davis, California, USA) and approximately 20,000 cpm rat $\left.{ }^{125} \mathrm{I}\right]-\mathrm{TSH}$ (Covance Inc., Vienna, Virginia, USA) were added in a $0.1-\mathrm{ml}$ aliquot and incubated for 24 hours at $4^{\circ} \mathrm{C}$. On the third day, antiguinea pig sera (1:25 dilution) were added as a $0.1-\mathrm{ml}$ aliquot and incubated for 24 hours at $4^{\circ} \mathrm{C}$. On the final day, the tubes were centrifuged at $2,500 \mathrm{~g}$ for 30 minutes at $4^{\circ} \mathrm{C}$, aspirated, and counted in a $\gamma$-counter. Samples were run in duplicate. The minimal detectable dose was $0.30 \mathrm{ng}$, and the intraand interassay variabilities were approximately $6 \%$ and $10 \%$, respectively.

Serum $T_{3}$ and $T_{4}$ levels were calculated according to the procedures and reagents provided by ICN Pharmaceuticals (Costa Mesa, California, USA) and Monobind Inc. (Costa Mesa, California, USA), respectively. The sensitivities of the $T_{3}$ and $T_{4}$ assays were $5.3 \mathrm{pg} / \mathrm{ml}$ and $0.16 \mathrm{ng} / \mathrm{ml}$, respectively, and the intra- and interassay variabilities were approximately $5-7 \%$ and $10-11 \%$, respectively.

\section{Acknowledgments}

These studies were supported in part by National Institute of Diabetes and Digestive and Kidney Diseases/NIH (NIDDK/NIH) grant R01 DK58148 and National Institute of Neurological Disorders and Stroke/NIH grant R01 NS045231 (to E.A. Nillni), NIDDK/NIH grant R01 DK60673 (to C. Bjorbaek), and NIDDK/ NIH grant R01 DA14659 (to T.C. Friedman).

Received for publication March 16, 2004, and accepted in revised form June 15, 2004.

Address correspondence to: Eduardo A. Nillni, Division of Endocrinology, Brown Medical School/Rhode Island Hospital, 55 Claverick Street, Fourth Floor, Room 400, Providence, Rhode Island 02903, USA. Phone: (401) 444-5733; Fax: (401) 444-6964; E-mail: Eduardo_Nillni@Brown.edu.
1. Seidah, N.G., and Chretien, M. 1997. Eukaryotic protein processing: endoproteolysis of precursor proteins. Curr. Opin. Biotechnol. 8:602-607.

2. Steiner, D.F. 1998. The proprotein convertases. Curr. Opin. Chem. Biol. 2:31-39.

3. Fricker, L. 1988. Carboxypeptidase E. Annu. Rev. Physiol. 50:309-321.

4. Dong, W., Fricker, L.D., and Day, R. 1999. Carboxypeptidase $\mathrm{D}$ is a potential candidate to carry out redundant processing functions of carboxypeptidase $\mathrm{E}$ based on comparative distribution studies in the rat central nervous system.
Neuroscience. 89:1301-1317.

5. Eipper, B.A., Stoffers, D.A., and Mains, R.E. 1992. The biosynthesis of neuropeptides: peptide $\alpha$-amidation. Annu. Rev. Neurosci. 15:57-85.

6. Nillni, E.A., and Sevarino, K.A. 1999. The biology of pro-thyrotropin-releasing hormone-derived peptides. Endocr. Rev. 20:599-648.

7. Schaner, P., Todd, R.B., Seidah, N.G., and Nillni, E.A. 1997. Processing of prothyrotropin releasing hormone by the family of prohormone convertases. J. Biol. Chem. 272:19958-19968.

8. Mains, R.E., and Eipper, B.A. 2000. Proopio- melanocortin (POMC) synthesis and cell-specific processing. In Handbook of physiology. Section 7, The endocrine system. Volume IV, Coping with the environment: neural and endocrine mechanisms. B.S. McEwen, editor. Oxford University Press. Oxford, United Kingdom. 85-101.

9. Benjannet, S., Rondeau, N., Day, R., Chretien, M., and Seidah, N.G. 1991. PC1 and PC2 are proprotein convertases capable of cleaving proopiomelanocortin at distinct pairs of basic residues. Proc. Natl. Acad. Sci. U. S. A. 88:3564-3568.

10. Nillni, E.A., et al. 2000. Leptin regulates prothyro- 
tropin-releasing hormone (proTRH) biosynthesis: evidence for direct and indirect pathways. J. Biol. Chem. 275:36124-36133.

11. Spiegelman, B.M., and Flier, J.S. 2001. Obesity and the regulation of energy balance. Cell. 104:531-543.

12. Schwartz, M.W., Woods, S.C., Porte, D.J., Seeley, R.J., and Baskin, D.G. 2000. Central nervous system control of food intake. Nature. 404:661-671.

13. Zhang, Y., et al. 1994. Positional cloning of the mouse obese gene and its human homologue. Nature. 372:425-432.

14. Pelleymounter, M.A., et al. 1995. Effects of the obese gene product on body weight regulation in $o b / o b$ mice. Science. 269:540-543.

15. Halaas, J.L., et al. 1995. Weight-reducing effects of the plasma protein encoded by the obese gene. Science. 269:543-546.

16. Campfield, L.A., Smith, F.J., Guisez, Y., Devos, R., and Burn, P. 1995. Recombinant mouse OB protein: evidence for peripheral signal linking adiposity and central neural networks. Science. 269:546-549.

17. Ahima, R.S., et al. 1996. Role of leptin in the neuroendocrine response to fasting. Nature. 382:250-252.

18. Flier, J.S., and Maratos-Flier, E. 1998. Obesity and the hypothalmus: novel peptides for new pathways. Cell. 92:437-440.

19. Seidah, N., et al. 1991. Cloning and primary sequence of a mouse candidate prohormone convertase PC1 homologous to PC2, furin, and Kex2: distinct chromosomal localization and messenger RNA distribution in brain and pituitary compared to PC2. Mol. Endocrinol. 5:111-122.

20. Seidah, N.G., et al. 1990. cDNA sequence of two distinct pituitary proteins homologous to Kex2 and furin gene products: tissue-specific mRNAs encoding candidates for pro-hormone processing proteinases [erratum 1990, 9:789]. DNA Cell Biol. 9:415-424.

21. Seidah, N.G., Chretien, M., and Day, R. 1994. The family of substilisin/kexin like pro-protein and prohormone convertase: divergent of shared functions. Biochimie. 76:197-209.

22. Winsky-Sommerer, R., et al. 2000. Regional and cellular localization of the neuroendocrine prohormone convertases PC1 and PC2 in the rat central nervous system. J. Comp. Neurol. 424:439-460.

23. Schafer, M.-H., et al. 1993. Gene expression of prohormone and proprotein convertases in the rat CNS: a comparative in situ hybridization analysis. J. Neurosci. 13:1258-1279.

24. Nillni, E.A., et al. 1995. ProTRH processing by recombinant PC1. J. Neurochem. 65:2462-2472.

25. Brakch, N., Galanopoulou, A.S., Patel, Y.C., Boileau, G., and Seidah, N.G. 1995. Comparative proteolytic processing of rat prosomatostatin by the convertases PC1, PC2, furin, PACE4, and PC5 in constitutive and regulated secretory pathways. FEBS Lett. 362:143-146.

26. Coates, L.C., and Birch, N.P. 1998. Differential cleavage of provasopressin by the major molecular forms of SPC3. J. Neurochem. 70:1670-1678.

27. Paquet, L., Massie, B., and Mains, R.E. 1996. Proneuropeptide $\mathrm{Y}$ processing in large dense-core vesicles: manipulation of prohormone convertase expression in sympathetic neurons using adenoviruses. J. Neurosci. 76:964-973.

28. Villeneuve, P., Seidah, N.G., and Beaudet, A. 2000. Immunohistochemical evidence for the implication of PC1 in the processing of proneurotensin in rat brain. Neuroreport. 11:3443-3447.

29. Johanning, K., et al. 1998. Specificity of prohormone convertase 2 on proenkephalin and proenkephalinrelated substrates. J. Biol. Chem. 273:22672-22680.

30. Dey, A., et al. 2003. Biological processing of the cocaine and amphetamine-regulated transcript precursors by prohormone convertases, PC2 and PC1/3. J. Biol. Chem. 278:15007-15014.

31. Zhu, X., et al. 2002. Disruption of PC1/3 expression in mice causes dwarfism and multiple neuroendocrine peptide processing defects. Proc. Natl. Acad. Sci. U. S. A. 99:10293-10298.

32. Furuta, M., et al. 1997. Defective prohormone processing and altered pancreatic islet morphology in mice lacking active SPC2. Proc. Natl. Acad. Sci.U.S. A. 94:6646-6651.

33. Laurent, V., et al. 2002. Mortality in 7B2 null mice can be rescued by adrenalectomy: involvement of dopamine in ACTH hypersecretion. Proc. Natl. Acad. Sci. U. S. A. 99:3087-3092.

34. Westphal, C.H., et al. 1999. The neuroendocrine protein $7 \mathrm{~B} 2$ is required for peptide hormone processing in vivo and provides a novel mechanism for pituitary Cushing's disease. Cell. 96:689-700.

35. Jackson, R., et al. 1997. Obesity and impaired prohormone processing associated with mutations in the human convertase 1 gene. Nat. Genet. 16:303-306.

36. Challis, B.G., et al. 2002. A missense mutation disrupting a dibasic prohormone processing site in pro-opiomelanocortin (POMC) increases susceptibility to early-onset obesity through a novel molecular mechanism. Hum. Mol. Genet. 11:1997-2004.

37. Naggert, J.K., et al. 1995. Hyperinsulinemia in obese fat/fat mice associated with a carboxypeptidase E mutation which reduces enzyme activity. Nat. Genet. 10:135-142.

38. Nillni, E., Mulcahy, L., Xie, W., Leiter, E.H., and Wetsel, W.C. 2002. Deficiencies in pro-thyrotropin-releasing hormone (pro-TRH) processing and abnormalities in thermoregulation in Cpefat/fat mice. J. Biol. Chem. 277:48587-48595.

39. de Lange, P., et al. 2001. Uncoupling protein-3 is a molecular determinant for the regulation of resting metabolic rate by thyroid hormone. Endocrinol ogy. 142:3414-3420.

40. Toni, R., and Lechan, R.M. 1993. Neuroendocrine regulation of thyrotropin-releasing hormone (TRH) in the tuberoinfundibular system. J. Endocrinol. Invest. 16:715-753.

41. Blake, N., Eckland, D., Foster, O., and Lightman, S. 1991. Inhibition of hypothalamic thyrotropinreleasing hormone messenger ribonucleic acid during food deprivation. Endocrinology. 129:2714-2718.

42. Rondeel, J.M., et al. 1992. Effect of starvation and subsequent refeeding on thyroid function and release of hypothalamic thyrotropin-releasing hormone. Neuroendocrinology. 56:348-353.

43. Bornstein, S.R., Torpy, D.J., Chrousos, G.P., Licinio, J., and Engelmann, L. 1997. Leptin levels are elevated despite low thyroid hormone levels in the "euthyroid sick" syndrome. J. Clin. Endocrinol. Metab. 82:4278-4279.

44. Steward, C.A., Horan, T.L., Schuhler, S., Bennett, G.W., and Ebling, F.J. 2003. Central administration of thyrotropin releasing hormone (TRH) and related peptides inhibits feeding behavior in the Siberian hamster. Neuroreport. 14:687-691.

45. Choi, Y.H., Hartzell, D., Azain, M.J., and Baile, C.A 2002. TRH decreases food intake and increases water intake and body temperature in rats. Physiol. Behav. 77:1-4.

46. Légrádi, G., Emerson, C.H., Ahima, R.S., Flier, J.S., and Lechan, R.M. 1997. Leptin prevents fastinginduced suppression of prothyrotropin-releasing hormone messenger RNA in neurons of the hypothalamic paraventricular nucleus. Endocrinology. 138:2569-2576.

47. Nillni, E.A., Luo, L.G., Jackson, I.M.D., and McMillan, P. 1996. Identification of the thyrotropin-releasing hormone precursor, its processing products, and its coexpression with convertase 1 in primary cultures of hypothalamic neurons: anatomic distribution of PC1 and PC2. Endocrinology. 137:5651-5661.

48. Benjannet, S., et al. 1993. Comparative biosynthesis, post-translational modifications and efficiency of prosegment cleavage of the prohormone convertases PC1 and PC2: glycosylation, sulphation and identification of the intracellular site of prosegment cleavage of PC1 and PC2. Biochem. J. 294:735-743.

49. Zhou, A., and Mains, R.E. 1994. Endoproteolytic processing of proopiomelanocortin and prohormone convertase 1 and 2 neuroendocrine cells overexpressing prohormone convertases 1 or 2. J. Biol. Chem. 269:17440-17447.

50. Vaisse, C., et al. 1996. Leptin activation of Stat3 in the hypothalamus of wild-type and $o b / o b$ mice but not $d b / d b$ mice. Nat. Genet. 14:95-97.

51. Bjørbæk, C., Uotani, S., da Silva, B., and Flier, J.S. 1997. Divergent signaling capacities of the long and short isoforms of the leptin receptor. J. Biol. Chem. 272:32686-32695.

52. Harris, M., et al. 2001. Transcriptional regulation of the thyrotropin-releasing hormone gene by leptin and melanocortin signaling. J. Clin. Invest. 107:111-120.

53. Bates, S.H., et al. 2003. STAT3 signalling is required for leptin regulation of energy balance but not reproduction. Nature. 421:856-859.

54. Huo, L., Munzberg, H., Nillni, E.A., and Bjorbaek, C. 2004. Role of signal transducer and activator of transcription 3 in regulation of hypothalamic trh gene expression by leptin. Endocrinology. 145:2516-2523.

55. Reidy, S.P., and Weber, J.M. 2002. Accelerated substrate cycling: a new energy-wasting role for leptin in vivo. Am. J. Physiol. Endocrinol. Metab. 282:E312-E317.

56. Fricker, L.D., et al. 2000. Identification and characterization of proSAAS, a granin-like neuroendocrine peptide precursor that inhibits prohormone processing. J. Neurosci. 20:639-648.

57. Muller, L., Zhu, X., and Lindberg, I. 1997. Mechanism of the facilitation of PC2 maturation by 7B2: involvement in ProPC2 transport and activation but not folding. J. Cell Biol. 139:625-638.

58. Pu, L.P., Ma, W., Barker, J., and Loh, Y.P. 1996. Differential expression of genes encoding prothyrotropin-releasing hormone (proTRH) and prohormone convertases (PC1 and $\mathrm{PC} 2$ ) in rat brain neurons: implications for differential processing of proTRH. Endocrinology. 137:1233-1241.

59. Nillni, E.A., Sevarino, K.A., and Jackson, I.M.D. 1993. Processing of proTRH to its intermediate products occurs before the packing into secretory granules of transfected AtT20 cells. Endocrinology. 132:1271-1277

60. Jansen, E., Ayoubi, T.A., Meulemans, S.M., and Van de Ven, W.J. 1997. Cell type-specific protein-DNA interactions at the cAMP response elements of the prohormone convertase 1 promoter. Evidence for additional transactivators distinct from CREB/ATF family members. J. Biol. Chem. 272:2500-2508.

61. Jansen, E., Ayoubi, T.A., Meulemans, S.M., and Van De Ven, W.J. 1997. Regulation of human prohormone convertase 2 promoter activity by the transcription factor EGR-1. Biochem. J. 328:69-74.

62. Bjorbaek, C., et al. 2001. Divergent roles of SHP-2 in ERK activation by leptin receptors. J. Biol. Chem. 276:4747-4755.

63. Duan, H.O., and Simpson-Haidaris, P.J. 2003. Functional analysis of interleukin 6 response elements (IL-6REs) on the human gamma-fibrinogen promoter: binding of hepatic Stat 3 correlates negatively with transactivation potential of type II IL-6REs. J. Biol. Chem. 278:41270-41281.

64. Li, Q.-L., et al. 2000. Interactions between the prohormone convertase 2 (PC2) promoter and the thyroid hormone receptor. Endocrinology. 141:3256-3266.

65. Li, Q.L., Jansen, E., Brent, G.A., and Friedman, T.C. 2001. Regulation of prohormone convertase 1 (PC1) by thyroid hormone. Am. J. Physiol. Endocrinol. Metab. 280:E160-E170.

66. Bergen, H.T., Mizuno, T., Taylor, J., and Mobbs, C.V. 1999. Resistance to diet-induced obesity is associated with increased proopiomelanocortin 
mRNA and decreased neuropeptide $Y$ mRNA in the hypothalamus. Brain Res. 851:198-203.

67. Elmquist, J.K., Bjørbæk, C., Ahima, R.S., Flier, J.S., and Saper, C.B. 1998. Distributions of leptin receptor mRNA isoforms in the rat brain. J. Comp. Neurol. 395:535-547.

68. Nillni, E.A., Aird, F., Seidah, N.G., Todd, R.B., and Koenig, J.I. 2001. PreproTRH178-199 and two novel peptides ( $\mathrm{pFQ7}$ and pSE14) derived from its processing, which are produced in the paraventricular nucleus of the rat hypothalamus, are regulated during suckling. Endocrinology. 142:896-906.

69. Nillni, E.A., Lee, A., Legradi, G., and Lechan, R.M. 2002. Effect of precipitated morphine withdrawal on post-translational processing of prothyrotropin releasing hormone (proTRH) in the ventrolateral column of the midbrain periaqueductal gray. J. Neurochem. 80:874-884.

70. Legradi, G., et al. 1996. Opiate withdrawal increases proTRH gene expression in the ventrolateral column of the midbrain periaqueductal gray. Brain Res. 729:10-19.

71. Gahn, L.G., and Sevarino, K.A. 1996. Preprothyrotropin-releasing hormone mRNA in the rat central gray is strongly and persistently induced during morphine withdrawal. Neuropeptides. 30:207-212.

72. Arancibia, S., Rage, F., Astier, H., and Tapia-Arancibia, L. 1996. Neuroendocrine and autonomous mechanisms underlying thermoregulation in cold environment. Neuroendocrinology. 64:257-267.

73. Kates, A.L., and Himms-Hagen, J. 1992. Effects of cold acclimation and fasting on thyroxine 5 '-deiodinase in brown adipose tissue of ob/ob mice. Proc. Soc. Exp. Biol. Med. 200:495-501.

74. Kates, A.L., and Himms-Hagen, J. 1990. Defective regulation of thyroxine $5^{\prime}$-deiodinase in brown adipose tissue of ob/ob mice. Am. J. Physiol. 258:E7-E15.

75. Rosenbaum, M., Murphy, E.M., Heymsfield, S.B., Matthews, D.E., and Leibel, R.L. 2002. Low dose leptin administration reverses effects of sustained weight-reduction on energy expenditure and circulating concentrations of thyroid hormones. J. Clin. Endocrinol. Metab. 87:2391-2394.

76. Garcia, S.I., et al. 2002. Thyrotropin-releasing hormone decreases leptin and mediates the leptininduced pressor effect. Hypertension. 39:491-495.

77. Garcia, S.I., et al. 2001. Thyrotropin-releasing hormone receptor (TRHR) gene is associated with essential hypertension. Hypertension. 38:683-687.

78. Bruhn, T.O., Rondeel, J.M.M., Bolduc, T.G., Luo, L.-G., and Jackson, I.M.D. 1996. Activation of thyrotropin-releasing hormone gene expression in cultured fetal diencephalic neurons by differentiating agents. Endocrinology. 137:572-579.

79. Benjannet, D.L., et al. 1992. Identification of the type 2 proinsulin processing endopeptidase as PC2, a member of the eukaryotic subtilisin family. J. Biol. Chem. 267:15229-15236.

80. Chomczynski, P., and Sacchi, N. 1987. Single-step method of RNA isolation by acid guanidinium thiocyanate-phenol-chloroform extraction. Biochemistry. 162:156-159.

81. Virca, G.D., Northemann, W., Shiels, B.R., Widera, G., and Broome, S. 1990. Simplified northern blot hybridization using 5\% sodium dodecyl sulfate. Biotechniques. 8:370-371.

82. Nillni, E.A., Sevarino, K.A., and Jackson, I.M.D. 1993. Identification of the thyrotropin-releasing hormone prohormone and its post translational processing in a transfected AtT20 cell line. Endocrinology. 132:1260-1270. 